OPEN ACCESS

Edited by:

Atya Kapley,

National Environmental Engineering Research Institute (CSIR-NEERI), India

Reviewed by:

Birthe V. Kjellerup, University of Maryland, College Park,

United States

Gaurav Saxena,

Jawaharlal Nehru University, India

Ying Teng,

Institute of Soil Science (CAS), China

${ }^{*}$ Correspondence:

Chirayu Desa

chirayudesai.bt@charusat.ac.in

Datta Madamwar

datta_madamwar@yahoo.com

Specialty section:

This article was submitted to Microbiotechnology,

a section of the journal

Frontiers in Microbiology

Received: 16 May 2020 Accepted: 06 October 2020

Published: 05 November 2020

Citation:

Patel AB, Shaikh S, Jain KR, Desai $C$ and Madamwar D (2020) Polycyclic Aromatic Hydrocarbons: Sources, Toxicity, and Remediation

Approaches

Front. Microbiol. 11:562813. doi: 10.3389/fmicb.2020.562813

\section{Polycyclic Aromatic Hydrocarbons: Sources, Toxicity, and Remediation Approaches}

\author{
Avani Bharatkumar Patel ${ }^{1}$, Shabnam Shaikh ${ }^{2}$, Kunal R. Jain ${ }^{1}$, Chirayu Desai2* and \\ Datta Madamwar ${ }^{1,2 *}$ \\ ${ }^{1}$ Post Graduate Department of Biosciences, UGC Centre of Advanced Study, Sardar Patel University, Anand, India, ${ }^{2}$ P. D. \\ Patel Institute of Applied Sciences, Charotar University of Science and Technology, Anand, India
}

Polycyclic aromatic hydrocarbons (PAHs) are widespread across the globe mainly due to long-term anthropogenic sources of pollution. The inherent properties of PAHs such as heterocyclic aromatic ring structures, hydrophobicity, and thermostability have made them recalcitrant and highly persistent in the environment. PAH pollutants have been determined to be highly toxic, mutagenic, carcinogenic, teratogenic, and immunotoxicogenic to various life forms. Therefore, this review discusses the primary sources of PAH emissions, exposure routes, and toxic effects on humans, in particular. This review briefly summarizes the physical and chemical PAH remediation approaches such as membrane filtration, soil washing, adsorption, electrokinetic, thermal, oxidation, and photocatalytic treatments. This review provides a detailed systematic compilation of the eco-friendly biological treatment solutions for remediation of PAHs such as microbial remediation approaches using bacteria, archaea, fungi, algae, and co-cultures. In situ and ex situ biological treatments such as land farming, biostimulation, bioaugmentation, phytoremediation, bioreactor, and vermiremediation approaches are discussed in detail, and a summary of the factors affecting and limiting $\mathrm{PAH}$ bioremediation is also discussed. An overview of emerging technologies employing multi-process combinatorial treatment approaches is given, and newer concepts on generation of value-added by-products during PAH remediation are highlighted in this review.

\footnotetext{
Keywords: toxicity, bioavailability, biostimulation, microbial remediation, integrated technologies
}

\section{INTRODUCTION}

Rapid industrialization and urbanization have resulted in numerous anthropogenic activities, which dump various pollutants in the environment, including polycyclic aromatic hydrocarbons (PAHs) (Mojiri et al., 2019). Due to their inherent properties, PAHs are persistent pollutants having a wide range of biological toxicity; remediation of PAHs from the environment has been a global concern. The PAH pollutants are ubiquitous, found equally in aquatic and terrestrial ecosystems as well as in the atmosphere (Adeniji et al., 2019). The rate of deposition of PAHs was found to accelerate in the soil/sediments due to their higher hydrophobicity and low aqueous solubility. They are strongly adsorbed onto soil particles, and therefore, the soil ecosystem becomes an ultimate sink for PAHs (Lu et al., 2011; Kuppusamy et al., 2017). Soil PAH pollution can be classified into 
three categories, i.e., unpolluted ( $\sum \mathrm{PAH}<200 \mathrm{ng} \cdot \mathrm{g}^{-1}$ ), weakly polluted (PAH 200-600 ng.g $\left.{ }^{-1}\right)$, and heavily polluted (PAH > 1,000 ng.g ${ }^{-1}$ ) (Wu et al., 2019).

The PAH pollution, either directly or indirectly, is strongly affecting the health and well-being of humans, along with other organisms across the planet (García-Sánchez et al., 2018). The choice of appropriate strategies for $\mathrm{PAH}$ remediation is always critical, as it is highly dependent on two major parameters: polluted matrix and environmental conditions (Kuppusamy et al., 2017). Different remediation methods involving physical, chemical, biological, and lately developed integrated approaches have been continuously applied at varying degree of success. Among the many remediation approaches, methods based on microorganisms for ecological restoration of PAH-polluted environments have been a well-evaluated approach (Kuppusamy et al., 2017; Malla et al., 2018; Mehetre et al., 2019). Recently, the integrated PAH remediation methods have also been reported for efficient mitigation of PAH pollutants. The aim of this review is to discuss current knowledge and recent developments in $\mathrm{PAH}$ remediation strategies, associated factors, and their effectiveness as well as limitations. This review also systematically outlines characteristics, sources, exposures, toxicity, and health effects of PAHs, as well as the significance of PAH remediation, insights of -omics approaches in $\mathrm{PAH}$ bioremediation, and constraints during $\mathrm{PAH}$ bioremediation.

\section{POLYCYCLIC AROMATIC HYDROCARBONS: PHYSICO-CHEMICAL PROPERTIES, SOURCES OF POLLUTION, AND ROUTES OF EXPOSURE}

Polycyclic aromatic hydrocarbons are organic pollutants and composed of two or more fused aromatic rings of carbon and hydrogen atoms, which are primarily colorless, white, or pale yellow solid compounds (Abdel-Shafy and Mansour, 2016; Suman et al., 2016). The molecular arrangements of aromatic rings in space can be linear, angular, or in clusters (AbdelShafy and Mansour, 2016). With the number of rings present in the compounds, PAHs are classified into light-molecular weight PAHs (LMW PAHs; having two or three aromatic rings) and high-molecular weight PAHs (HMW PAHs; having four or more aromatic rings). Depending upon their molecular weight, they are emitted either as gaseous phase (LMW PAHs) or in the particulate form (HMW PAHs) (Lee and Vu, 2010). Further, based on the structure of rings, PAHs are also classified as: alternant $P A H s$, which contain only fusion of six carbon benzene rings, whereas the non-alternant $P A H s$ like fluorene contain fusion of six carbon benzene rings along with an additional ring of less than six carbon (Gupte et al., 2016). The existence of dense $\pi$ electrons on aromatic rings is responsible for the biochemical persistence of PAHs that make PAHs more resistant to nucleophilic attack (Haritash and Kaushik, 2009). The United States Environmental Protection Agency (USEPA) has declared 16 PAHs as priority pollutants in 1983 based on their existence of highest concentrations, greater exposure, recalcitrant nature, and toxicity (Zheng et al., 2018; Mojiri et al., 2019). PAHs are characterized through their low water solubility, low vapor pressure, and high melting and boiling points, depending on their structures (Lee and $\mathrm{Vu}, 2010$ ). PAHs with increased molecular weight are tending to decrease water solubility and increase lipophilicity, making them more recalcitrant compounds (Okere and Semple, 2012). Table 1 shows the physicochemical properties of 16 PAHs.

The sources of PAH pollution are categorized mainly into two, such as anthropogenic emission sources and natural emission sources (Mojiri et al., 2019). Natural emission sources such as volcanic eruptions, natural forest fire, and moorland fire caused by lightning flashes are negligible or less important (Srogi, 2007; Ravindra et al., 2008; Abdel-Shafy and Mansour, 2016). Anthropogenic emission sources are the main determinants of $\mathrm{PAH}$ pollution, which can be divided into four types, i.e., industrial, mobile, domestic, and agricultural emission sources (Ravindra et al., 2008). Incomplete combustion is the prime source of $\mathrm{PAH}$ emissions by various industrial activities such as waste incineration, iron and steel production, aluminum production, cement manufacturing, coal-tar pitch production, dye manufacturing, asphalt industries, rubber tire manufacturing, fungicide and insecticide production, exhaust from refineries, and power production (Srogi, 2007; Ravindra et al., 2008; Abdel-Shafy and Mansour, 2016; Gupte et al., 2016; Mojiri et al., 2019). Other industrial emission sources are coal gasification, electric arc furnace, oxygen furnace, diesel engine, and gasoline-powered engines of large machineries (Srogi, 2007; Ravindra et al., 2008). Mobile emission sources include exhaust from many vehicles like aircrafts, ships, trains, and off-road heavyweight and lightweight vehicles (Srogi, 2007; Ravindra et al., 2008).

Domestic emission sources involve household activities such as garbage burning, coal coking, wood burning, cooking on oil/gas burners and kerosene/wood stoves, and other residential heating (Johnsen and Karlson, 2007; Ravindra et al., 2008; Gupte et al., 2016). Agricultural emission sources are open biomass burning and agricultural waste burning when burning is performed under suboptimum combustion conditions (Ravindra et al., 2008). High PAH pollution in a rural area is mainly due to domestic and agricultural sources, whereas in an urban area due to industrial, mobile, and domestic sources. PAH concentration varies in all seasons; concentration is highest in winter followed by spring, autumn, and summer. The higher $\mathrm{PAH}$ level in winter and spring can be attributed to the high quantity of incomplete combustion of fossil fuel, elevated residential heating, lower photodegradation, and poor diffusion due to atmospheric conditions like calm winds and low temperature (Miura et al., 2019). Figure 1 shows different types of PAH emission sources.

The PAH sources are also categorized based on their origin of production into three types, i.e., pyrogenic, petrogenic, and biogenic (Mojiri et al., 2019). Pyrogenic PAHs are formed through unintentionally incomplete combustion of organic materials at very high temperatures $\left(350-1,200^{\circ} \mathrm{C}\right)$ under no or low oxygen conditions (Abdel-Shafy and Mansour, 2016). Some intentional pyrolytic processes such as thermal breaking of petroleum complex compounds into lighter hydrocarbons 
TABLE 1 | Physicochemical properties of 16 polycyclic aromatic hydrocarbons (Yan et al., 2004; Bojes and Pope, 2007; Ravindra et al., 2008; Lee and Vu, 2010; Ghosal et al., 2016).

\begin{tabular}{|c|c|c|c|c|c|c|c|c|c|c|c|}
\hline Name & Formula & Structure & $\begin{array}{l}\text { Molecular weight } \\
\text { (g/mole) }\end{array}$ & $\begin{array}{l}\text { Solubility in water } \\
\quad(\mathrm{mg} / \mathrm{L})\end{array}$ & $\begin{array}{c}\text { Phase } \\
\text { distribution }\end{array}$ & $\begin{array}{l}\text { Melting } \\
\text { point }\left({ }^{\circ} \mathrm{C}\right)\end{array}$ & $\begin{array}{c}\text { Boiling } \\
\text { point }\left({ }^{\circ} \mathrm{C}\right)\end{array}$ & $\begin{array}{l}\text { Vapor pressure } \\
\quad(\mathrm{mmHg})\end{array}$ & Log Kow & Log Koc & $\begin{array}{c}\text { Toxicity as per } \\
\text { IARC }\end{array}$ \\
\hline Naphthalene & $\mathrm{C}_{10} \mathrm{H}_{8}$ & & 128.17 & 31 & Gas & 80.26 & 218 & 0.087 & 3.29 & 2.97 & $2 \mathrm{~B}$ \\
\hline Acenaphthene & $\mathrm{C}_{12} \mathrm{H}_{10}$ & & 154.21 & 3.8 & Gas & 95 & 96 & $4.47 \times 10^{-3}$ & 3.98 & 3.66 & 3 \\
\hline Acenaphthylene & $\mathrm{C}_{12} \mathrm{H}_{8}$ & & 152.20 & 16.1 & Gas & $92-93$ & $265-275$ & 0.029 & 4.07 & 1.40 & 3 \\
\hline Anthracene & $\mathrm{C}_{14} \mathrm{H}_{10}$ & & 178.23 & 0.045 & Particle gas & 218 & 340-342 & $1.75 \times 10^{-6}$ & 4.45 & 4.15 & 3 \\
\hline Phenanthrene & $\mathrm{C}_{14} \mathrm{H}_{10}$ & & 178.23 & 1.1 & Particle gas & 100 & 340 & $6.8 \times 10^{-4}$ & 4.45 & 4.15 & 3 \\
\hline Fluorene & $\mathrm{C}_{13} \mathrm{H}_{10}$ & & 166.22 & 1.9 & Gas & $116-117$ & 295 & $3.2 \times 10^{-4}$ & 4.18 & 3.86 & 3 \\
\hline Fluoranthene & $\mathrm{C}_{16} \mathrm{H}_{10}$ & & 202.26 & 0.26 & Particle gas & 110.8 & 375 & $5.0 \times 10^{-6}$ & 4.90 & 4.58 & 3 \\
\hline Benzo(a)anthracene & $\mathrm{C}_{20} \mathrm{H}_{12}$ & & 228.29 & 0.011 & Particle & 158 & 438 & $2.5 \times 10^{-6}$ & 5.61 & 5.30 & 2B \\
\hline Chrysene & $\mathrm{C}_{18} \mathrm{H}_{12}$ & & 228.29 & 0.0015 & Particle & 254 & 448 & $6.4 \times 10^{-9}$ & 5.9 & No data & $2 \mathrm{~B}$ \\
\hline Pyrene & $\mathrm{C}_{16} \mathrm{H}_{10}$ & & 202.26 & 0.132 & Particle gas & 156 & $393-404$ & $2.5 \times 10^{-6}$ & 4.88 & 4.58 & 3 \\
\hline Benzo(a)pyrene & $\mathrm{C}_{20} \mathrm{H}_{12}$ & & 252.32 & 0.0038 & Particle & 179-179.3 & 495 & $5.6 \times 10^{-9}$ & 6.06 & 6.74 & 1 \\
\hline Benzo(b)fluoranthene & $\mathrm{C}_{20} \mathrm{H}_{12}$ & & 252.32 & 0.0015 & Particle & 168.3 & No data & $5.0 \times 10^{-7}$ & 6.04 & 5.74 & $2 \mathrm{~B}$ \\
\hline Benzo(k)fluoranthene & $\mathrm{C}_{20} \mathrm{H}_{12}$ & & 252.32 & 0.0008 & Particle & 215.7 & 480 & $9.59 \times 10^{-11}$ & 6.06 & 5.74 & $2 \mathrm{~B}$ \\
\hline
\end{tabular}


and distillation of coal into coal tar and coke also produce pyrogenic PAHs. The concentrations of pyrogenic PAHs are generally higher in urban areas (Abdel-Shafy and Mansour, 2016; Mojiri et al., 2019). Petrogenic PAHs are present in petroleum and its by-products that are widespread due to storage, transport, use, and leakage of crude oil and its products (Abdel-Shafy and Mansour, 2016). Pyrogenic sources are predominated by HMW PAHs, and petrogenic sources consist majorly of LMW PAHs (Marris et al., 2020). Biogenic PAHs are synthesized by biological entities like microorganisms, phytoplankton, algae, and plants and during slow biological conversion of organic materials (Mojiri et al., 2019).

Atmospheric PAHs (gaseous phase as aerosols) are deposited in water, soil, and plants in the particulate phase through dry/wet deposition processes (Abdel-Shafy and Mansour, 2016). PAHs with three or more aromatic rings are very strong adsorbent to the soil particles due to low vapor pressure and high hydrophobicity (Abdel-Shafy and Mansour, 2016). Accumulation of PAHs in soil/sediment is responsible for further transport of pollution to the groundwater, plants, and food, e.g., plant roots absorb PAHs from polluted soil and translocate to the farther plant parts. Exposure to PAHs is unavoidable in the current situation. PAH exposure occurs mainly via three routes, i.e., inhalation, ingestion, and dermal contact (Burchiel and Luster, 2001). It is also possible that exposure can occur via more than one route, simultaneously, e.g., dermal and inhalation exposures from contaminated soil (Rengarajan et al., 2015; Abdel-Shafy and Mansour, 2016). For many people, the primary exposure occurs at the workplace, e.g., workers in coke manufacturing factories and food processing industries, traffic police through inhalation of vehicle exhaust and road dust containing PAHs (Lee and $\mathrm{Vu}$, 2010). All are not workplace-based exposure, such as consuming polluted water, grilled and smoked food items, smoking, etc. (Lee and $\mathrm{Vu}, 2010$; Suman et al., 2016). For smoking people, one cigarette causes an intake of 20-40 ng of benzo(a)pyrene (Skupinska et al., 2004). Up to $70 \%$ of PAH exposure can be related to diet for non-smoking persons (Skupinska et al., 2004).

In drinking water, PAH concentration varies between $1 \mathrm{ng} / \mathrm{L}$ and $11 \mu \mathrm{g} / \mathrm{L}$, and the highest acceptance by WHO for benzo(a)pyrene is $0.7 \mu \mathrm{g} / \mathrm{L}$ (Skupinska et al., 2004). PAHs are formed during domestic and industrial food processing like roasting, toasting, drying, grilling, frying, baking, and barbecuing (Rose et al., 2015). Vegetables and fruits may be contaminated by their growth in PAH-polluted soil and atmospheric deposition (Zelinkova and Wenzl, 2015). The world's two most popular beverages, tea and coffee, are also contaminated with PAHs through atmospheric deposition on raw plants, industrial drying/roasting processes, and heating steps in preparation (Duedahl-Olesen et al., 2015). Duedahl-Olesen et al. (2015) investigated the presence of PAH4 [chrysene, benzo(a)pyrene, benzo(a)anthracene, benzo(b)fluoranthene] in 18 brands of tea and 13 brands of coffee. The highest PAH4 was detected in black tea $(25-115 \mu \mathrm{g} / \mathrm{kg})$ and in instant coffee $(2.2-5.1 \mu \mathrm{g} / \mathrm{kg})$.

As per report of the German Environment Agency, PAHs are found in using products, e.g., toys, bathing shoes, mouse pads, bicycle handles, many sports items, etc., daily (Brandt and Einhenkel-Arle, 2016). The desired elasticity of rubber-made 


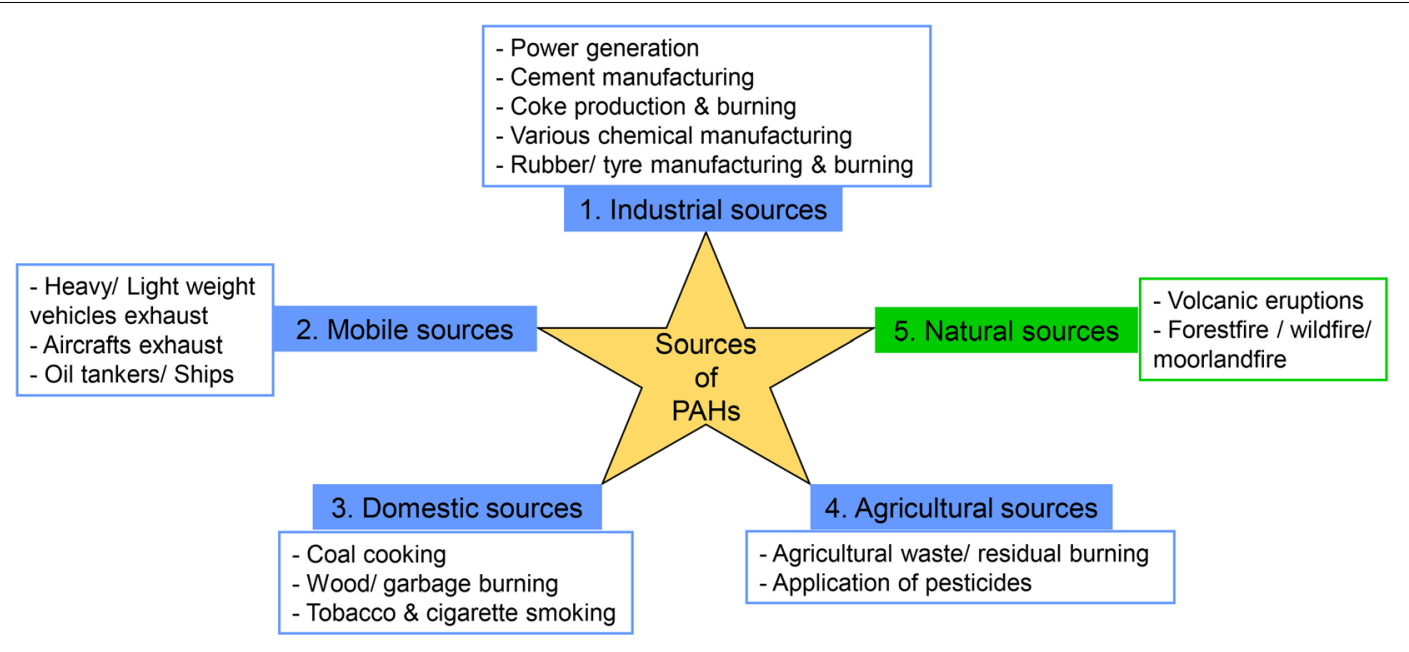

FIGURE 1 | Different types of polycyclic aromatic hydrocarbon (PAH) emission sources: 1, 2, 3, and 4 belong to anthropogenic activities, and 5 belongs to natural activities.

products and softness and flexibility in polyvinyl chloride (PVC)-made products are achieved using tar oils, extender oils, and industrial soots, which have extended PAHs. The PVC bathing shoes were found to have $546 \mathrm{mg} / \mathrm{kg}$ of 16 PAHs, among all, fluorene and phenanthrene levels were highest, 170 and $120 \mathrm{mg} / \mathrm{kg}$, respectively. Paschke et al. (2015) detected benzo(a)pyrene, pyrene, phenanthrene, and naphthalene in newspaper's ink at levels up to 52, 553, 778, and $283 \mu \mathrm{g} / \mathrm{kg}$, respectively. PAHs are inevitable in life even though they have toxic effects because of their presence in daily usable products including foodstuffs.

\section{BIOTOXICITY OF NOXIOUS POLYCYCLIC AROMATIC HYDROCARBON POLLUTANTS}

Individual PAH compounds do not have the exact same health effects (Rengarajan et al., 2015; Abdel-Shafy and Mansour, 2016). Many PAHs are mutagenic, carcinogenic, teratogenic, and immunotoxic to living organisms, including microorganisms, animals, and humans (Burchiel and Gao, 2014; Rengarajan et al., 2015; Bolden et al., 2017). PAHs have ecotoxic effects on aquatic life and birds (Abdel-Shafy and Mansour, 2016). The mode of exposure, exposure duration, and exposure dose are important parameters for the severity of PAHs' toxic effects (Rajpara et al., 2017; Tong et al., 2018). Zheng et al. (2018) found that PAHs from different sources showed different risk levels, and they calculated incremental lifetime cancer risk (ILCR) in humans for soil-bound PAHs upon the three different exposure routes; the highest cancer risk was found for ingestion, i.e., 98.1-99.3\%, followed by dermal contact, i.e., $0.66-1.83 \%$, and inhalation, i.e., $0.03-0.04 \%$. Toxic effects of PAHs may vary according to factors such as pre health status and age. Acute health effects include eye irritation, vomiting, diarrhea, confusion, skin irritation, and inflammation (Abdel-Shafy and Mansour, 2016). Naphthalene, anthracene, and benzo(a)pyrene are direct skin irritants and skin sensitizers for animals and humans (Rengarajan et al., 2015). Chronic health effects include eye cataracts, kidney and liver damages, breathing problems, decreased immune function, lung malfunctions, and asthma-like symptoms (Abdel-Shafy and Mansour, 2016). Naphthalene can cause the breakdown of red blood cells if inhaled or ingested in high amounts (Rengarajan et al., 2015).

\section{Phototoxicity of Polycyclic Aromatic Hydrocarbons}

Sunlight has three components, i.e., 91.0\% visible light (400$700 \mathrm{~nm}), 8.7 \%$ UVA light (320-400 nm), and 0.3\% UVB light (280-320 nm) (Yan et al., 2004). PAHs can absorb UVA and visible light. Due to the absorption of UVA light, formation of reactive species upon electron or energy transfer from the excited PAHs and formation of reactive intermediates upon the reaction of excited PAHs with oxygen or other molecules occur in the cells. These reactive species or intermediates are responsible for damages to cellular components such as cell membrane, nucleic acid, or proteins. PAH-contaminated human skin exposed to sunlight irradiation can cause DNA singlestrand cleavage, oxidation of DNA bases, and formation of DNA covalent adducts, indicating PAH toxicity can exceed over 100 times in the presence of light as compared to dark (Yu, 2002; Yan et al., 2004).

\section{Genotoxicity and Carcinogenicity}

Polycyclic aromatic hydrocarbon detoxification in mammalian systems occurs mainly in the liver via catalytic reactions of cytochrome P450 and many oxidase enzymes by generating water-soluble epoxide glutathione conjugates (Yu, 2002; AbdelShafy and Mansour, 2016). However, metabolism of some PAHs also generates reactive intermediates (e.g., diolepoxides, quinones, hydroxyalkyl derivatives), which are not sufficiently 
polar to be excreted, they form covalent adducts with nucleic acid and lead to genotoxic effects (Abdel-Shafy and Mansour, 2016). The International Agency for Research on Cancer (IARC) has categorized PAHs in four groups, i.e., group 1 as carcinogenic to humans, group $2 \mathrm{~A}$ as probably carcinogenic to humans, group $2 \mathrm{~B}$ as possibly carcinogenic to humans, and group 3 as not classifiable as carcinogenic to humans (Ghosal et al., 2016; Table 1). Benzo(a)pyrene is considered one of the most carcinogenic PAHs and generally used as an exposure marker for risk assessments (Lee and Vu, 2010). Tong et al. (2018) suggested that there is a $45 \%$ possibility of carcinogenic risk if $\mathrm{PAH}$ exposure exceeds the acceptable threshold $\left(10^{-6}\right)$. Significant accumulation and bioavailability of PAHs in the internal organs, which are rich in adipose tissue, after exposure are due to the high lipophilicity (Lee and Vu, 2010; Abdel-Shafy and Mansour, 2016). Several organs susceptible to tumor formation due to long-term exposure to PAHs include lung, skin, esophagus, colon, pancreas, bladder, and women's breast (Yu, 2002; Rajpara et al., 2017).

\section{Teratogenicity and Human Reproductive System Abnormalities}

Embryo toxicity has been reported in experimental animals due to exposure to naphthalene, benzo(a)anthracene, and benzo(a)pyrene (Rengarajan et al., 2015; Abdel-Shafy and Mansour, 2016). As per the scoping review by Bolden et al. (2017), these compounds may act as antiestrogens and/or antiandrogens by directly binding with estrogen and androgen receptors. Bolden et al. (2017) noted many non-cancer reproductive system-related health effects in both males and females due to PAH exposure, such as changes in sperm quality, testicular function, and egg viability, as well as DNA damage in oocytes, ovarian damages, and other reproductive diseases. The human studies evaluated affected health outcomes like polycystic ovary syndrome, fertility, spontaneous abortion, and premature birth.

The important hormonal regulators of reproduction such as luteinizing hormone, follicle-stimulating hormone, gonadotrophin-releasing hormone, and aromatase enzyme may be impacted by PAHs (Bolden et al., 2017). Smith et al. (2007) explained that benzo(a)pyrene induced infertility in the male reproductive system. Children do not require higher exposure for the same adverse health effects as adults. Children are prone to behaviors for increased $\mathrm{PAH}$ exposure, e.g., eating polluted soil, crawling on bare dirt surfaces, and many more hand-mouth activities. The Center for Children's Environmental Health reports demonstrate that exposure of PAHs during pregnancy is responsible for adverse birth outcomes like low weight, premature delivery, and heart malformations (Rengarajan et al., 2015). High prenatal PAH exposure is connected to a low IQ and increased behavioral problems in the early-age child and childhood asthma (Perera et al., 2014; Rengarajan et al., 2015).

\section{Immunotoxicity of Polycyclic Aromatic Hydrocarbons}

Polycyclic aromatic hydrocarbons have some immune system-related adverse effects like inhibition of pre B, pre
$\mathrm{T}$, and myeloid cell development, $\mathrm{B}$ and $\mathrm{T}$ cell suppression, apoptosis of lymphoid tissues, disruption of myelopoiesis, and altered cytokine production by macrophages and monocytes (Burchiel and Luster, 2001; Burchiel and Gao, 2014; Rengarajan et al., 2015). Under specific circumstances, tumor development, hypersensitivity (allergy), and autoimmunity may develop (Abdel-Shafy and Mansour, 2016). PAHs bind with specific aryl hydrocarbon receptors (AhRs) in lymphocytes and accessory cells of the immune system, upregulate AhR-controlled metabolic enzymes cytochrome $\mathrm{P} 450$, and produce immune toxic oxidative and electrophilic metabolites (Burchiel and Gao, 2014; Marris et al., 2020). The required PAH concentration to suppress humoral and cell-mediated immunity in mice is extremely high, 10$50 \mathrm{mg} / \mathrm{kg}$ of benzo(a)pyrene (Burchiel and Gao, 2014). Exposure to PAHs alters the structural and functional changes in bone marrow, which cause crucial health consequences, as bone marrow is the central organ of hematopoiesis and vital site for the production of immune system cells (Hrudkova et al., 2004). The required PAH concentration is higher to produce immunotoxicity than to produce cancer (Burchiel and Gao, 2014).

\section{ANALYSIS OF POLYCYCLIC AROMATIC HYDROCARBON POLLUTANTS IN ENVIRONMENTAL SAMPLES}

Analytical techniques for PAH characterization in environmental samples involve extraction and detection techniques. Drawbacks of conventional solid-phase extraction and liquid-liquid extraction methods are overcome by advanced extraction methods, mainly classified as microextraction methods and miniaturized extraction methods (Manousi and Zachariadis, 2020). Microextraction methods include various solid-phase microextraction (SPME) (e.g., flow injection and syringe SPME) and various liquid-phase microextraction (LPME) (e.g., single-drop and hollow-fiber LPME, dispersive liquidliquid microextraction, ultrasound/vortex-assisted LPME). Miniaturized extraction methods include dispersive solid-phase extraction, stir bar/rod/plate sorptive extraction, magnetic solid-phase extraction, fabric-phase sorptive extraction, and pipette tip solid-phase extraction. PAH extraction is improved by implementation of novel sorbents in advanced extraction methods like metal-organic frameworks, zeolitic imidazole frameworks, graphene, carbon nanotubes, graphene oxide, and molecularly imprinted polymers. Hazardous organic solvents are replaced with ionic liquids in LPME. Benefits of advanced extraction methods are simplicity, less time-consuming steps, less solvent requirements, lower volume samples, and easy handling (Manousi and Zachariadis, 2020). The most applicable detection methods are high-performance liquid chromatography (HPLC), gas chromatography (GC), gas chromatographymass spectrometry (GC-MS), and ultra-high-pressure LC along with UV detector, diode-array detector, tandem-mass 
detector, flame ionization detector, and fluorescence detector (Manousi and Zachariadis, 2020).

\section{PHYSICAL AND CHEMICAL METHODS FOR POLYCYCLIC AROMATIC HYDROCARBON REMEDIATION}

Remediation strategies implicate the reduction of pollutants in the environment until safe levels are attained by degradation or transformation processes in air, water, and soil. Pollution caused by PAHs is an onerous global concern due to their adverse effects. To restore the environment from $\mathrm{PAH}$ pollution, various remediation strategies have been employed including physical, chemical, and biological methods.

Due to the hydrophobic property of PAHs, they are soluble in organic solvents like acetone, alcohol, hexane, dichloromethane, methyl ethyl ketone, toluene, etc. Therefore, the use of suitable individual solvents or a mixture of solvents can be used to remove PAHs from water, sludge, and soil (Peng X. et al., 2018). Soil washing with solvent is a suitable approach for the removal of HMW PAHs, which are difficult to remove from the soil due to their low bioavailability and strong affinity to soil (Kuppusamy et al., 2017). Non-toxic and biodegradable extraction agents, e.g., cyclodextrins, vegetable oil, humic acid, supercritical and subcritical fluids, can also be used in the soil washing method (Gan et al., 2009). Solvent regeneration can be possible by distillation with the approximate loss of $10 \%$ solvent. Soil washing is recognized as a highly efficient method, which can be integrated along with other methods to achieve maximum degradation (Gitipour et al., 2018). Use of surfactant may enhance the efficiency of soil washing by changing the solubility of PAHs. Surfactantaided soil washing was strongly dependent on PAH properties, surfactant structure, and soil composition (Gan et al., 2009; Gitipour et al., 2018).

Various membrane-based filtration methods such as ultrafiltration, micro/nano-filtration, and reverse osmosis can be applied for PAH removal from water (Smol and WłodarczykMakuła, 2012; Smol et al., 2016; Li et al., 2019). Gong et al. (2017) investigated electrocoagulation integrated membrane filtration approach for $\mathrm{PAH}$ removal from paper making wastewater (PMWW) to achieve water quality that is reusable, and they reported $94 \%$ of PAH removal from electrocoagulated PMWW using low-pressure reverse osmosis membranes at $25^{\circ} \mathrm{C}$. Several adsorbents like activated carbon, charcoal, biochar, modified clay, magnetic nanomaterials, graphene oxide, nano-sulfonated graphene (SGE), and electro spun nanofibers have been used to remove PAHs from water and soil (Lamichhane et al., 2016; Xinhong et al., 2017).

Xinhong et al. (2017) selected nano-SGE over Tween 80 and methyl- $\beta$-cyclodextrin as in situ soil washing agent for PAH removal from coking plant soil, and they reported $80 \%$ of PAH removal under optimum washing conditions, which were 2,000 mg. $\mathrm{L}^{-1}$ concentration of SGE, 10:1 ratio of liquid/soil, and four cycles of successive washing. SGE properties such as strong adsorption capabilities for pollutants, high surface area for adsorption, high dispersibility, and separate deposition during centrifugation with soil make an ideal soil washing agent (Xinhong et al., 2017). Biochar has better adsorption for HMW PAHs than LMW PAHs because biochar needs a very high temperature for activation, at which LMW PAHs may be converted into gaseous phase (Peng $X$. et al., 2018). The $\mathrm{PAH}$ removal rate is highly affected by factors like reaction temperature, $\mathrm{pH}$, humidity, concentration of adsorbent, etc. (Peng X. et al., 2018).

In situ electrokinetic remediation can be applied to PAHpolluted soils having less hydraulic conductivity by applying direct low-intensity electric current through electrodes (Kuppusamy et al., 2017). This method is more efficient with solubilizing agents of PAHs such as solvents, surfactants, vegetable oil, and cyclodextrins and more advantageous when it is applied with other in situ biodegradation methods (Kuppusamy et al., 2017). Li et al. (2020) assessed electro-bioremediation approach for pilot-scale PAH removal from polluted soil of an abandoned coking plant site. Degradation of total PAHs was achieved $-69 \%$ by electro-bioremediation approach as compared to $29 \%$ by only bioremediation after 182 days of incubation ( $\mathrm{Li}$ et al., 2020). Thermal technologies include incineration of PAHs from polluted soil and industrial wastes at high temperatures $\left(900-1,200^{\circ} \mathrm{C}\right)$ that destroy or volatilize the PAHs (Gan et al., 2009; Kuppusamy et al., 2017). In situ incineration is quite safe due to slight or no PAH emission into the atmosphere during heating because it uses a vacuum system or carrier gas for sweeping the volatile PAHs in the attached gas treatment arrangement for secondary removal of PAHs (Kuppusamy et al., 2017). The major disadvantage of incineration technology is a high energy requirement that makes it costly.

Most physical methods simply transfer PAHs from water and soil, but there are no structural changes in PAHs; therefore, physical methods cannot completely remove PAHs from the environment. Due to time-consuming and inefficient role of physical methods for PAH removal, chemical methods have been gaining attention (Peng X. et al., 2018). The most common approach for PAH removal by chemical methods is oxidation processes using common oxidants like ozone $\left(\mathrm{O}_{3}\right)$ and Fenton reagent $\left(\mathrm{Fe}^{2+}+\mathrm{H}_{2} \mathrm{O}_{2}\right)$ as well as other oxidants like potassium permanganate $\left(\mathrm{KMnO}_{4}\right)$, peroxy-acid (R-COOH), hydrogen peroxide $\left(\mathrm{H}_{2} \mathrm{O}_{2}\right)$, and activated sodium persulfate $\left(\mathrm{Na}_{2} \mathrm{~S}_{2} \mathrm{O}_{8}\right)$ (Ukiwe et al., 2013; Das and Das, 2015; Peng X. et al., 2018). During oxidation through the Fenton reagent, unstable hydroxyl radicals $(\bullet \mathrm{OH})$ are generated in the presence of ferrous iron $\left(\mathrm{Fe}^{2+}\right)$, which are utilized to degrade PAHs either by hydrogen abstraction or by hydroxyl addition (equations 1-3) (Gong et al., 2017). The requirements of acidic pH $(2.8-3.0)$ during the oxidation process and ferric iron $\left(\mathrm{Fe}^{3+}\right)$ removal after oxidation are the disadvantages, which make Fenton oxidation impractical and expensive as well as disturbing soil quality and soil microbes (Mojiri et al., 2019). These can be overcome by applying modified Fenton oxidation at neutral $\mathrm{pH}$ using chelating agents (capable of maintaining iron in dissolved form) along with Fenton reagents such as 
cyclodextrins, EDTA, citric acid, humic acid, oxalic acid, catechol, etc. (Usman et al., 2016).

$$
\begin{gathered}
\mathrm{H}_{2} \mathrm{O}_{2}+\mathrm{Fe}^{2+} \rightarrow \bullet \mathrm{OH}+\mathrm{OH}^{-}+\mathrm{Fe}^{3+} \\
\mathrm{RH}+\bullet \mathrm{OH} \rightarrow \bullet \mathrm{R}+\mathrm{H}_{2} \mathrm{O} \\
\mathrm{R}+\bullet \mathrm{OH} \rightarrow \bullet \mathrm{ROH}
\end{gathered}
$$

The efficiency of ozone oxidation is strongly dependent on the water content of PAH-polluted soil; increased water content has an adverse effect since PAHs become less accessible to ozone due to occupied pore spaces by water (Gan et al., 2009). HMW PAHs are less susceptible to ozone and Fenton reagent oxidation due to their stronger affinities with humic acid of soil (Gan et al., 2009). The use of ultraviolet radiation or addition of other oxidants along with ozone can improve the oxidation rate (Ukiwe et al., 2013). Limitation of low aqueous solubility and low vapor pressure of PAHs during chemical degradation can be overcome by adding surfactants (Ukiwe et al., 2013; Gupte et al., 2016). The activation (heat, alkaline, and iron) aids to achieve better results than original oxidation treatments (Peluffo et al., 2018). Song et al. (2019) investigated PAH removal at in situ pilot-scale by different Zero-valent iron (ZVI)-activated persulfate oxidations and found PAH removal efficiencies 82, 63, and $69 \%$ by nanostructured ZVI, stearic-coated nanostructured ZVI, and micron-sized ZVI-activated persulfate oxidations, respectively, within 104 days of treatments.

Zhao et al. (2013) showed that thermal activation at $60^{\circ} \mathrm{C}$ and use of citrate chelated ferrous iron $\left(\mathrm{Fe}^{2+}\right)$ along with persulfate oxidation enhanced HMW and total $\mathrm{PAH}$ removal (99 and 83\%) as compared to control (persulfate oxidation without activation and addition) in the polluted soil of the coking plant due to generation of more powerful and stable persulfate $\left(\bullet \mathrm{SO}_{4}{ }^{1-}\right)$ and hydroxyl radicals $(\bullet \mathrm{OH})$. The oxidation process is affected by various factors like temperature, $\mathrm{pH}$, divalent iron ion concentration, hydrogen peroxide concentration, oxidant selection, dose of oxidants, age of polluted soil, soil type, etc. (Lemaire et al., 2013). Addition of insufficient chemical oxidants results in dead-end products that are resistant to further degradation. The dead-end products become the source of further pollution if biological remediation for them is not available (Ukiwe et al., 2013).

Photocatalysis is an important approach to remove PAHs from the environment. Photocatalytic materials such as titanium dioxide $\left(\mathrm{TiO}_{2}\right)$, zinc oxide $(\mathrm{ZnO})$, silicon dioxide $\left(\mathrm{SiO}_{2}\right)$, etc., can be used with ultraviolet light (Jiang et al., 2018). Titanium dioxide is the most effective photocatalytic material for removal of PAHs because of its higher oxidability and stability (Wen et al., 2003). Photochemical PAH degradation involves some oxidative species, which are produced during chemical oxidation of PAHs (Ukiwe et al., 2013).

\section{BIOREMEDIATION OF POLYCYCLIC AROMATIC HYDROCARBON POLLUTANTS}

Biological methods are environment-friendly and have gained a lot of attention for $\mathrm{PAH}$ remediation recently due to several drawbacks of physical and chemical methods including cost, procedural complexity, regulatory burden, and lack of complete degradation (Agnello et al., 2016; Ghosal et al., 2016). Bioremediation techniques are broadly classified as ex situ or in situ. Ex situ techniques involve the physical removal of the contaminated materials (soil: excavation and water: pumping) to another area possibly within the site for treatment. In situ techniques involve treatment of the contaminated material in place, which have great public consent due to less expense, minimal site interruption, and high possibility of permanent waste elimination (Shah, 2014).

\section{Microbial Remediation of Polycyclic Aromatic Hydrocarbon Pollution}

As per Kuppusamy et al. (2017), biological methods have gained wide attentions for $\mathrm{PAH}$ remediation, followed by integrated methods, chemical oxidation, and physical methods. Among all biological methods for $\mathrm{PAH}$ remediation, usage frequency of natural attenuation, bioaugmentation, and biostimulation is highest $(\sim 33 \%)$, followed by bioreactors (22\%), phytoremediation/rhizoremediation (22\%), composting (13\%), biopiles (4\%), enzyme-mediated bioremediation (2\%), vermiremediation (2\%), and others (2\%) (Kuppusamy et al., 2017). Moreover, the second most attractive integrated methods are applied in the subsequent order, i.e., biological-biological (42\%), chemical-biological (27\%), physical-chemical (21\%), physical-chemical-biological (5\%), and thermal-chemical methods (5\%) (Kuppusamy et al., 2017). Microbial PAH remediation (bioaugmentation and biostimulation) deals with separate or combined application of specific microbes such as bacteria, archaea, fungi, and algae. However, bacteria- and fungi-assisted degradation has been widely studied.

\section{Bacteria}

Bacteria have unique metabolic versatility for degradation of PAH pollutants (Ma and Zhai, 2012). During bacterial aerobic $\mathrm{PAH}$ degradation, the oxygen works as the final electron acceptor and also as a co-substrate for the hydroxylation and oxygen-mediated cleavage of the aromatic ring (Chen et al., 2016), whereas bacterial anaerobic PAH degradation utilizes an entirely diverse approach to break and open the aromatic ring depending on the reductive reaction type and alternative final electron acceptors (Ghosal et al., 2016; Dhar et al., 2020). Chiefly, the bacteria perform aerobic PAH degradation using oxygenase-facilitated metabolism (comprising monooxygenase and dioxygenase enzymes). The first step in the aerobic PAH degradation is the hydroxylation of the aromatic ring through dioxygenase enzymes and formation of the cis-dihydrodiol, which ultimately oxidized to diol intermediates with the help of dehydrogenase enzymes. 
These diol intermediates finally break open through the action of intra diol or extra diol ring-breaking dioxygenases via either ortho-cleavage or meta-cleavage pathway, able to form intermediates such as catechol, gentisic acids, and protocatechuic acid, which finally transform to tricarboxylic acid (TCA) cycle intermediates (Mallick et al., 2011). Dioxygenase is the multienzyme complex usually comprising of reductase, ferredoxin, and terminal oxygenase subunits (Mallick et al., 2011; Ghosal et al., 2016; Wu et al., 2020). Bacteria also strategize PAH degradation by the cytochrome P450-assisted pathway with the formation of trans-dihydrodiols or anaerobically under nitrate- and sulfatereducing conditions (Lu et al., 2011; Mallick et al., 2011; Yang et al., 2020). Although aerobic PAH degradation is conventional and preferable, anaerobic $\mathrm{PAH}$ degradation is gaining more attentions nowadays due to the presence of anoxic conditions in diverse environmental niches such as phreatic zone, deep aquatic sediment, and water-flooded soil (Ghosal et al., 2016; Dhar et al., 2020).

The aerobic and anaerobic bacterial species have been reported extensively in the literature for the degradation of LMW and HWM PAHs through pure cultures, consortia, and mixed bacterial culture approaches (Table 2). The enhanced or complete PAH degradation can be achieved by mixed bacterial cultures and bacterial consortia as results of collaborative catabolic activities of participants and possibly presence of diverse degradation pathways. Therefore, most of the recent studies emphasized on mixed bacterial culture- and consortia-assisted PAH degradation (Vaidya et al., 2018; Haleyur et al., 2019; Patel et al., 2019). Degradation by immobilized bacteria and genetically modified bacteria is also a considerable approach (Peng X. et al., 2018). One of the major difficulties for degradation in soil/sediment is a dispersion of inoculum; it is easy for surface soil, however, challenging for subsurface soil due to limited microbial transport as cells adhere strongly to soil organic matter.

The immobilization of delivering inoculum microbes can serve the solution by increasing shelf life and activities of microbes in the soil system (Mrozik and PiotrowskaSeget, 2010). Huang et al. (2016) reported enhanced pyrene and indeno[1,2,3-cd]pyrene degradation (71 and $81 \%$ ) in petroleum-contaminated soil using immobilized Pseudomonas taiwanensis PYR1 and Acinetobacter baumannii INP1 on cinder beads. Immobilization provides biological stability to inoculum microbes, protection from suboptimum substandard environmental conditions, and reduced competition with indigenous microbes (Mrozik and Piotrowska-Seget, 2010). Apart from mesophilic bacteria, bacterial extremophiles such as halophilic, acidophilic, and thermophilic have also been reported for PAH degradation (Table 2). Application of thermotolerant and thermophilic bacteria for PAH degradation is beneficial, as elevated temperature causes increased diffusion of PAHs by decreasing viscosity, ultimately increasing the bioavailability of PAHs (Mehetre et al., 2019). Over the last decade, bacterial community analysis (Muangchinda et al., 2018; Yang et al., 2020), biochemical pathways in bacteria for PAH degradation (Chen et al., 2016; Vaidya et al., 2017), degradation-associated bacterial genes (Peng T. et al., 2018; Sangkharak et al., 2020), enzyme systems (Chen et al., 2016; Wu et al., 2020), and gene regulation of PAH degradation processes (Kan et al., 2020; Wu et al., 2020) have been researched enormously.

\section{Archaea}

Extreme environmental habitats, particularly saline regions, are most vulnerable to petroleum pollution due to their close connection with oil industries, which mostly release many pollutants, including PAHs, and demand extremophiles rather than conventional microorganisms for bioremediation (Dastgheib et al., 2012). Over the past few years, archaea have drawn the attention of researchers for PAH bioremediation, although few research studies have been reported (Table 2). The degradation pathways and mechanisms behind bioremediation via archaea have not been extensively studied like bacteria (Khemili-Talbi et al., 2015). Khemili-Talbi et al. (2015) isolated biosurfactant-producing halophilic arhaeon Natrialba sp. C21 from oil-polluted saline water for degradation of phenol, naphthalene, and pyrene at very high salinity conditions $(25 \% \mathrm{NaCl})$. They also attempted to find the degradation pattern via enzyme assays such as catechol 1,2-dioxygenase, catechol 2,3-dioxygenase, protocatechol 3,4-dioxygenase, and protocatechol 4,5-dioxygenase. The maximum activity of catechol 1,2-dioxygenase indicated that degradation occurred via the ortho-cleavage pathway.

\section{Fungi}

Mycoremediation of PAHs has been widely reported in the past several years with numerous fungal species. Unlike bacteria, all fungi do not utilize PAHs as a sole source of carbon; rather, they co-metabolize the PAHs and generate a range of oxidized products including $\mathrm{CO}_{2}$. The fungi execute monooxygenase enzyme-mediated $\mathrm{PAH}$ degradation (Gupta and Pathak, 2020). Mainly two types, i.e., ligninolytic fungi (white-rot fungi) and non-ligninolytic fungi, have been reported in the literature for LMW and HMW PAH bioremediation (Table 2). Ligninolytic fungi produce enzymes such as lignin peroxidase, manganese peroxidase, and laccases for degradation of lignin present in the wood and simultaneously oxidize the PAHs and convert into diphenol intermediates that eventually oxidize into quinones (Aydin et al., 2017). Ligninolytic enzymes generate water-soluble polar products after catalytic cleavage of aromatic compounds, which are eventually available for fungal metabolism and soil microflora present in the vicinity (Gupta and Pathak, 2020).

On the other hand, non-ligninolytic fungi produce cytochrome P450 monooxygenase-like enzymes, which oxidize the PAHs and lead to form arene oxide and water; further, arene oxides through non-enzymatic rearrangement form phenols, which conjugate with xylose, gluconeric acid, and glucose (Cerniglia and Sutherland, 2010; Ghosal et al., 2016). Some fungal species are also capable of producing biosurfactants in order to overcome the hindrance of less soluble HMW PAHs, which resulted in better degradation (Ojha et al., 2019). Limited studies have been reported on the mechanisms and pathways involved in the breakdown of PAHs through mycoremediation (Aydin et al., 2017; Agrawal et al., 2018). Direct fungi application in the field has many limitations including inadequate biomass 
TABLE 2 | Polycyclic aromatic hydrocarbon biodegradation under aerobic and anaerobic conditions using bacteria, archaea, fungi, algae, and co-cultures.

\begin{tabular}{|c|c|c|c|c|}
\hline Inoculum & PAHs used in the study & Degradation condition & Degradation (\%) & References \\
\hline \multicolumn{5}{|l|}{ Bacteria } \\
\hline $\begin{array}{l}\text { Mixed bacterial cultures DAK11: Pseudomonas } \\
\text { aeruginosa DAK11.1, Pseudomonas stutzeri } \\
\text { DAK11.2, Achromobacter sp. DAK11.3, and } \\
\text { Chelatococcus sp. DAK11.4 }\end{array}$ & $\begin{array}{l}\text { Naphthalene, Phenanthrene, } \\
\text { Fluoranthene, and Pyrene }\end{array}$ & Liquid medium Aerobic & $75,86,76$, and 76 & Patel et al., 2018 \\
\hline $\begin{array}{l}\text { Immobilized Pseudomonas taiwanensis PYR1 } \\
\text { and Acinetobacter baumannii INP1 on cinder } \\
\text { beads }\end{array}$ & Pyrene and Indeno[1,2,3-cd]pyrene & $\begin{array}{l}\text { Petroleum-contaminated } \\
\text { soil Aerobic }\end{array}$ & 71 and $81 \%$ & Huang et al., 2016 \\
\hline Bacterial community & 16 Priority PAHs & $\begin{array}{l}\text { In situ Windrows of } 5,000 \\
\text { tons polluted soil Aerobic }\end{array}$ & $85 \%$ total PAHs & Lors et al., 2012 \\
\hline $\begin{array}{l}\text { Microbial community associated with anaerobic } \\
\text { sediment }\end{array}$ & $\begin{array}{l}16 \text { Priority PAHs (with nitrate and } \\
\text { sulfate) }\end{array}$ & Sediment Anaerobic & 37,21, and $28 \%$ & Yang et al., 2020 \\
\hline \multicolumn{5}{|l|}{ Extremophiles } \\
\hline $\begin{array}{l}\text { Halophilic consortia Qphe-SublV Halomonas } \\
\text { strain and unculturable strain belonging to the } \\
\text { genus Marinobacter }\end{array}$ & Phenanthrene & $\begin{array}{l}\text { Liquid medium ( } 5 \% \mathrm{NaCl}) \\
\text { Aerobic }\end{array}$ & $>90 \%$ & $\begin{array}{l}\text { Dastgheib et al., } \\
2012\end{array}$ \\
\hline $\begin{array}{l}\text { Acidophilic Stenotrophomonas maltophilia } \\
\text { AJH1 }\end{array}$ & $\begin{array}{l}\text { Anthracene, Phenanthrene, } \\
\text { Naphthalene, Fluorene, Pyrene, } \\
\text { Benzo(e)pyrene, and } \\
\text { Benzo(k)fluoranthene }\end{array}$ & $\begin{array}{l}\text { Liquid medium }(\mathrm{pH} 2) \\
\text { Aerobic }\end{array}$ & $\begin{array}{l}91,90,96,95,86 \\
82, \text { and } 79 \%\end{array}$ & $\begin{array}{l}\text { Arulazhagan et al., } \\
2017\end{array}$ \\
\hline $\begin{array}{l}\text { Thermophilic Mix culture: Aeribacillus pallidus } \\
\text { U2, Bacillus axarquiensis UCPD1, Bacillus } \\
\text { siamensis GHP76, and Bacillus subtilis subsp. } \\
\text { inaquosorum U277 }\end{array}$ & $\begin{array}{l}\text { Anthracene, Fluorene, Phenanthrene, } \\
\text { and Pyrene }\end{array}$ & $\begin{array}{l}\text { Liquid medium At } 50^{\circ} \mathrm{C} \\
\text { Aerobic }\end{array}$ & $\begin{array}{l}96,86,54, \text { and } \\
71 \%\end{array}$ & Mehetre et al., 2019 \\
\hline \multicolumn{5}{|l|}{ Archaea } \\
\hline $\begin{array}{l}\text { Indigenous halophilic archaean Haloferax } \\
\text { elongans, Halobacterium noricense, Haloferax } \\
\text { larsenii, Halobacterium salinarum, and } \\
\text { Halobacterium sp. }\end{array}$ & Phenanthrene & $\begin{array}{l}\text { Soil and liquid medium } \\
\text { Aerobic }\end{array}$ & $\begin{array}{l}28,29,28,37 \text {, and } \\
22 \%\end{array}$ & Al-Mailem et al., 2017 \\
\hline $\begin{array}{l}\text { Haloarchaea strains: Ten strains of Haloferax } \\
\text { sp. }\end{array}$ & $\begin{array}{l}\text { Naphthalene, Anthracene, } \\
\text { Phenanthrene, Pyrene, and } \\
\text { Benzo(a)anthracene }\end{array}$ & $\begin{array}{l}\text { Hypersaline petroleum } \\
\text { produced water }(20 \% \mathrm{NaCl}) \\
\text { Aerobic }\end{array}$ & $20-80 \%$ & Bonfá et al., 2011 \\
\hline \multicolumn{5}{|l|}{ Ligninolytic fungi } \\
\hline Candida tropicalis NN4 & Indeno[1,2,3-cd] pyrene & Liquid medium Aerobic & $91 \%$ & Ojha et al., 2019 \\
\hline $\begin{array}{l}\text { Fungal mycelia: Armillaria mellea, Pleurotus } \\
\text { ostreatus, Pleurotus eryngii, and Stropharia ferii }\end{array}$ & Anthracene and Benzo(a)pyrene & Contaminated soil Aerobic & 95 and $50 \%$ & $\begin{array}{l}\text { Baldantoni et al., } \\
2017\end{array}$ \\
\hline \multicolumn{5}{|l|}{ Non-ligninolytic fungi } \\
\hline Cladosporium sp. CBMAI 1237 & $\begin{array}{l}\text { Anthracene, Acenaphthene, Fluorene, } \\
\text { Phenanthrene, Fluoranthene, and } \\
\text { Pyrene }\end{array}$ & Liquid medium Aerobic & $\begin{array}{l}71,78,70,47,52 \\
\text { and } 62 \%\end{array}$ & Birolli et al., 2018 \\
\hline Lasiodiplodia theobromae & Benzo(a)pyrene & Garden soil Aerobic & $92 \%$ & Wang et al., 2014 \\
\hline \multicolumn{5}{|l|}{ Algae } \\
\hline $\begin{array}{l}\text { Selenastrum capricornutum and Scenedesmus } \\
\text { acutus }\end{array}$ & Benzo(a)pyrene & Liquid medium Aerobic & 99 and $95 \%$ & $\begin{array}{l}\text { De Llasera et al., } \\
2016\end{array}$ \\
\hline Rhodomonas baltica & $\begin{array}{l}\text { Phenanthrene, Fluoranthene, and } \\
\text { Pyrene }\end{array}$ & Liquid medium Aerobic & $70 \%$ & Arias et al., 2017 \\
\hline \multicolumn{5}{|l|}{ Co-cultures } \\
\hline $\begin{array}{l}\text { Bacterial-fungal consortium: Serratia } \\
\text { marcescens L-11, Streptomyces rochei } \\
\text { PAH-13, and Phanerochaete chrysosporium } \\
\text { W-18 }\end{array}$ & $\begin{array}{l}\text { Fluorene, Anthracene, Phenanthrene, } \\
\text { and Pyrene }\end{array}$ & $100 \mathrm{~g}$ soil in pot, Aerobic & $\begin{array}{l}98,66,90, \text { and } \\
55 \%\end{array}$ & Sharma et al., 2016 \\
\hline $\begin{array}{l}\text { Bacterial-algal synergy: Chlorella sp. MM3 and } \\
\text { Rhodococcus wratislaviensis } 9\end{array}$ & $\begin{array}{l}\text { Phenanthrene, Pyrene, and } \\
\text { Benzo(a)pyrene }\end{array}$ & Soil slurry Aerobic & $100 \%$ & $\begin{array}{l}\text { Subashchandrabose } \\
\text { et al., } 2019\end{array}$ \\
\hline
\end{tabular}

growth, huge biomass handling difficulties, lack of application methodologies, and bulk degrading enzyme production, which can be overcome by oxidative fungal enzyme-mediated PAH bioremediation (Harms et al., 2011).

\section{Algae}

Algae, the primary producers in coastline and estuarine ecosystems, may have a significant role in PAH bioremediation within aquatic ecosystems. Alga-mediated effective PAH 
removal occurs through cellular biodegradation and/or bioaccumulation (Ke et al., 2010). PAH biodegradation employs both monooxygenase and dioxygenase enzymatic pathways and produces hydroxylated and dihydroxylated intermediates, respectively, depending on the algal type (Chan et al., 2006). Microalgae (Cyanobacteria) are freshwater unicellular green alga, have gained huge attention for its ubiquitous occurrence, easy to propagate, and most prominent efficiency of degrading HMW PAHs (Ke et al., 2010; De Llasera et al., 2016). Few reports on alga-based PAH bioremediation are listed in Table 2. Many alga-based $\mathrm{PAH}$ removal studies at the laboratory or microcosm scale have been reported in the literature, although large- or fieldscale alga-mediated $\mathrm{PAH}$ remediation remains to be uncovered and requires scientific attention to develop successful strategies.

\section{Co-cultures}

Co-culturing approaches such as bacterial-fungal co-cultures, fungal-algal synergy, and bacterial-algal synergy are proven as the most efficient bioremedial approaches at the laboratory as well as large-scale applications (Sharma et al., 2016; Subashchandrabose et al., 2019; Table 2). During aerobic degradation, algae supply oxygen to enhance degradation. The bacterial-algal synergy is more advantageous over bacterial consortia and bacterial-fungal co-cultures because algae provide various extra polymeric and lightweighted compounds (consist of lipids, proteins, nucleic acids, fermentation products, etc.), which promote bacterial and/or fungal growth and thus enhance $\mathrm{PAH}$ degradation (Kuppusamy et al., 2017).

\section{Microbial Enzyme-Mediated Bioremediation}

Microbial enzyme-mediated bioremediation involves the use of isolated enzymes from bacteria, fungi, and other living organisms for PAH removal. The enzymatic action is extremely efficient and selective due to higher reaction rates and the capability to catalyze reactions at a wide range of temperature and $\mathrm{pH}$. Oxygenase, dehydrogenase, lignin peroxidase, manganese peroxidase, laccases, and phenoloxidases are enzymes responsible for PAH oxidation as mentioned in above subsections (Mohan et al., 2006). The oxidative enzymes from fungi are more efficient because they are less substrate-specific enzymes (Harms et al., 2011; Gupta and Pathak, 2020). Zhang et al. (2020) isolated novel manganese peroxidase gene from Cerrena unicolor BBP6 and cloned into Pichia pastoris, which had various dye-decolorizing ability along with 80 and $91 \%$ of fluorene and phenanthrene degradation activity within $24 \mathrm{~h}$, and the highest recombinant enzyme expression was 154.5 Unit. $\mathrm{L}^{-1}$. The only drawback of this method is cost related to production, extraction, and purification of enzymes (Kuppusamy et al., 2017).

\section{Strategies for Polycyclic Aromatic Hydrocarbon Bioremediation}

Land farming is a cost-effective and safe treatment for polluted land, in which the native microbiome at a polluted site is stimulated for $\mathrm{PAH}$ degradation via improving aeration, moisture, and nutrient levels so that the connection of microbes is improved with pollutants and nutrients (Agnello et al., 2016;
Kuppusamy et al., 2017). The reduction rate is much higher for LMW PAHs (2-3 rings) than HMW PAHs (4-6 rings), and this method is applied usually for a thin layer of land surface (Das and Das, 2015; Silva-Castro et al., 2015; García-Sánchez et al., 2018). This simple method requires less maintenance, nearly no cleanup obligations, and slight monitoring efforts. Limitations are slow degradation rate after initial rapid degradation rate due to the concentration gradient of pollutants, affected only superficial 10$35-\mathrm{cm}$ accessible soil layer, and largely influenced by surrounding uncontrollable and unintentional conditions like heavy rainfall (Gan et al., 2009).

Natural attenuation method enhances the degradation capacities of innate microbiome by improving aeration, moisture, and nutrient levels. If natural attenuation is performed on polluted land, then it is a good example of land farming method. Chikere et al. (2017) reported 98\% total petroleum hydrocarbon and $85 \%$ poly aromatic hydrocarbon degradation by enhanced natural attenuation in crude oil-polluted field-scale bioremediation after. The enhanced natural attenuation was processed by nutrient addition ( $\mathrm{N}: \mathrm{P}: \mathrm{K}$ ratio 2:1:1), tilling, periodic water irrigation, and intermittent turning of soil to make sure there was uniform aeration (Chikere et al., 2017).

Biostimulation is a remediation method in which the activities of indigenous microbes can be encouraged by the addition of nutrients $(\mathrm{N}, \mathrm{P}, \mathrm{S}$, and $\mathrm{K})$, slow/fast releasing fertilizers, organic wastes, humic acid, and/or terminal electron acceptor. It is basically used to overcome limitations of microbial growth and activities. Different combinations of macro- and micro- nutrients are used to enhance PAH degradation (Das and Das, 2015). Patel et al. (2019) tested NPK fertilizer, urea fertilizer, and AS fertilizer as biostimulating agents to enhance phenanthrene and fluoranthene degradation by mixed bacterial cultures. Biostimulation can also be performed through an adaptation approach in which high pre-exposure of target pollutants are applied for adaptation of selective organisms having the capacity to survive and utilize target pollutants (Mohan et al., 2006).

A new era of nanobiotechnology leads to the development of a more competitive biostimulation approach for rapid $\mathrm{PAH}$ remediation based on the use of nanofertilizers and nanominerals, which enable broader distribution of nutrients in deeper soil (Kuppusamy et al., 2017). A time interval study conducted by Bianco et al. (2020) on the effects of anaerobic biostimulation such as digestate, fresh organic fraction of solid municipal waste, and combination of micro-/macronutrients (ratio of soil and biostimulants was 10:1) on the degradation of the four PAH mixture (200 mg. kg-1 of anthracene, phenanthrene, pyrene, and fluoranthene) in marine sediment at $37^{\circ} \mathrm{C}$ and $130 \mathrm{rpm}$ confirmed biostimulation efficiency for $\mathrm{PAH}$ degradation (55\%) compared to control without any supplementation (12\%). The application of digestate and organic waste as biostimulants during degradation signifies the economic perspective as well as encourages the renewable remediation strategy (Bianco et al., 2020). Blood meal is a dark-colored complex non-toxic liquid of animal origin, which acts as a slow releasing fertilizer and is rich with lysine, valine, leucine, tryptophan, and histidine. Recently, biostimulation using blood meal along with weekly soil plowing was studied for in situ 
bioremediation of dichlorodiphenyltrichloroethane (DDT)- and PAH-polluted farmland soil (Wang et al., 2017).

Composting is one of the most preferable and cost-effective remediation methods for pollutant degradation in soil, which improves soil organic content and soil fertility, and it is one type of biostimulation in which organic content is added (Chen et al., 2015). Composting remediation is more successful for 3and 4-ring PAHs than 5- and 6-ring PAHs, as higher ring PAHs may negatively affect the microbial activities of compost and their natural bioavailability was low (Gan et al., 2009; Guo et al., 2020). The compost bulking agents such as spent mushroom, soot waste, agricultural wastes, maple leaves, cow manure, pig manure, activated sludge, etc., can be used in PAH degradation that support the enhancement of microbial population and raise the required temperature for degradation (Mohan et al., 2006; Shah, 2014; Das and Das, 2015). Guo et al. (2020) studied biodegradation of PAHs in polluted sewage sludge by a cocomposting method using green forest waste. The experiments were performed with three different rations of sewage sludge and green forest waste. PAH degradation (75.2\%) was highest in ratio $3: 2$, followed by ratio $3: 1(70.7 \%)$ and ratio 3:3 (62.4\%) after 50 days of composting in compost windrows $(1.5 \mathrm{~m}$ width $\times 1.2 \mathrm{~m}$ height $\times 10 \mathrm{~m}$ length).

Bioaugmentation is the introduction of inoculum of pollutantdegrading single microorganisms or group of microorganisms to achieve optimum degradation and sometimes to improve the catabolic capacities of indigenous microbes (Das and Das, 2015). It is effective, rapid, easily publicly adaptable, easily applicable, and versatile alternative for PAH degradation; nevertheless, unpredictable (Kong et al., 2018). Application of the bioaugmentation strategy for $\mathrm{PAH}$ degradation may include bacteria, archaea, fungi, and algae as pure cultures as well as mixed cultures; detailed description is presented in the section Microbial Remediation of Polycyclic Aromatic Hydrocarbon Pollution (Ghosal et al., 2016). The degradation of PAHs by microorganisms occurs in the presence of oxygen and in the absence of oxygen, which are called aerobic degradation and anaerobic degradation, respectively. In anaerobic biodegradation, microbes use other substances such as nitrate, sulfate, iron, manganese, and carbon dioxide as electron exchanger during degradation and produce carbon dioxide and methane as the final products. Anaerobic biodegradation is helpful to remediate the deep underground soil where oxygen is absent or very low (Gan et al., 2009).

Bioreactor is an ex situ controlled system for efficient PAH degradation; addition of non-ionic surfactants, bioaugmentation with useful microbes, and/or biostimulation with additional nutrients enhance PAH bioremediation process in bioreactors (Mohan et al., 2006). Soil column and soil slurry bioreactors degrade effectively the soil-bound contaminants under controlled and optimized conditions. The continuous fed batch reactors (anaerobic-anoxic-aerobic, $5 \mathrm{~L}$ each) were proved to be potential for $300 \mathrm{mg} \cdot \mathrm{L}^{-1}$ of naphthalene degradation (99\%) in influent wastewater from coke oven industry along with sulfate and ammonical nitrogen as biostimulants and cow dung slurry as inoculum by Yadu et al. (2019). Forján et al. (2020) designed a pilot- scale soil slurry bioreactor for PAH-polluted factory soil in which dissolved oxygen $(8 \mathrm{mg} / \mathrm{L}), \mathrm{pH}(\sim 8)$, and temperature $\left(28^{\circ} \mathrm{C}\right)$ probes were constantly controlled. Soil slurry bioreactor was prepared by combined approach of biostimulation (C:N:P ratio of 100:10:1) and bioaugmentation using Rhodococcus erythropolis, which reported 89.3, 79.7, 72.0, and $82.1 \%$ degradation of 2-ring, 3-ring, 4-6-ring, and total PAHs, respectively, after 15 days of bioreactor process (Forján et al., 2020).

Phytoremediation is an in situ method in which the plants are used to remove PAHs or to convert them into less harmful components in soil, sediment, surface water, and groundwater (Das and Das, 2015). Plants remediate the organic pollutants by different mechanisms such as phytoextraction (withdrawal of pollutants from soil), phytovolatilization (atmospheric release of volatile pollutants from soil via plant organs), and phytodegradation (degradation of pollutants by enzymes released from plant and/or plant-associated microbes) (GarcíaSánchez et al., 2018). Plants help in soil aeration by increasing permeability and by cracking soil masses, which favor PAH aerobic biodegradation (Gitipour et al., 2018).

During phytoremediation, plants resist easily a range of environmental assaults due to their sessile characteristic. Plants are selected ideally based on their quality to grow at a polluted site and growth time, biomass productivity, ability to support active soil microbial population, capability to degrade pollutants, and capability to adapt to environmental conditions (Cook and Hesterberg, 2013). Economic viewpoint suggests phytoremediation with grass is preferable due to less maintenance, low nutrient requirements, robust growth, tolerance for sought, acidic and, cold conditions, and their very fibrous root system, which may help enhance soil microbial activities (Gan et al., 2009; Cook and Hesterberg, 2013).

He and Chi (2019) investigated phytoremediation capabilities of two submerged aquatic plants, Vallisneria spiralis and Hydrilla verticillata, in PAH-polluted sediments at pilot scale. The experiment was conducted for 108 days, and results indicated that dissipation of phenanthrene and pyrene was highest in sediment planted with V. spiralis (85.9 and $79.1 \%$ ), followed by sediment planted with $H$. verticillata (76.3 and 64.6\%) and unplanted sediment (76.3 and 64.6\%). Higher dissipation of phenanthrene and pyrene in planted sediments was due to plantsupported biodegradation and plant uptake (He and Chi, 2019). Phytoremediation of soil polluted by fly ash PAHs using willows of Salix $\times$ smithiana Willd (checked) was used to remove $50.9 \%$ PAHs after 3 years of treatment (checked), which was higher as compared to $9.9 \%$ ash PAH removal by natural attenuation in soil (Košnáø et al., 2020).

Rhizoremediation is one specific subset of phytoremediation, in which plant-associated rhizosphere microorganisms are used for treatment of polluted soils (Das and Das, 2015). Rhizoremediation is more intensive for PAH degradation and a key of successful rhizoremediation is dependent on the appropriate partnership of plant and microbes that have degradation capabilities (Agnello et al., 2016; Eskandary et al., 2017). Plants provide the huge root surface area for microbial growth and remediate pollutants approximately $10-15 \mathrm{~m}$ deep 
in the soil (Bisht et al., 2015). In rhizoremediation, plant roots supply the nutrients for growth and activities of PAHdegrading microbes in the form of carbohydrates, amino acids, flavonoids, and organic acids, whereas microbes compensate by supporting the plants to conquer against stress generated due to pollutants and reduce the phytotoxicity (Bisht et al., 2015; Eskandary et al., 2017). Kong et al. (2018) conducted fieldscale PAH degradation study $(3 \mathrm{~m} \times 1.2 \mathrm{~m}, 0.4 \mathrm{~m}$ depth, and 5 tons soil) for 175 days in aged polluted soil of 50-yearold coking plants.

Comparison of four different methods indicated that microbeassociated phytoremediation (Rhodococcus ruber Em1 associated with Orychophragmus violaceus) was superlative among natural attenuation, bioaugmentation (Rhodococcus ruber Em1), and phytoremediation (Orychophragmus violaceus). R. ruber Em1 combined with $O$. violaceus significantly enhanced the removal of $16 \mathrm{PAHs}, 54 \%$ as compared to 18,30 , and $36 \%$ in other methods. The removal of HMW PAHs with 4-6 rings were much greater by microbe-associated phytoremediation methods (55\%) as compared to natural attenuation $(10 \%)$ and phytoremediation (20\%) (Kong et al., 2018). García-Sánchez et al. (2018) also compared four different $\mathrm{PAH}$ bioremediation approaches via pot experiments with $5 \mathrm{~kg}$ of aged polluted soil for 180 days. They found a microbe-associated phytoremediation approach using maize plants along with white rod fungi and indigenous microorganisms as the most beneficial for removal of LMW, HMW, and total 16 PAHs as compared to other approaches, i.e., natural attenuation, myco-augmentation using white rod fungi Crucibulum leave, and phytoremediation using maize plants (García-Sánchez et al., 2018).

The advantages of phytoremediation and rhizoremediation as compared with other approaches are that they preserve the natural conditions of the soil, energy is derived primarily from sunlight, high level of microbial biomass in the soil can be achieved, and both are cost-effective and environmentfriendly methods. The major drawbacks of both methods are the site where plants cannot grow, large land requirement, limited remediation depth, only applicable for low-level polluted site (plant tolerance level), highly dependent on climate and seasonal conditions, disposal of accumulated PAHs from plant parts, unknown effects of biodegradation products, risk for pollutants to enter the food chain, and uncertainty in treatment duration prediction (Gan et al., 2009; Bisht et al., 2015; Gitipour et al., 2018).

Vermiremediation is used as individual and combined with microbes or plants for PAH removal from fine soil (pores size $<0.1 \mu \mathrm{m}$ ). PAHs in pores of fine soil are not bioavailable and bioaccessible for degrading bacteria (size 1-10 $\mu \mathrm{m}$ ) and plant root hairs (size 15-17 $\mu \mathrm{m}$ ). During vermiremediation, burrowing actions of earthworms enlarge the soil pore size; therefore, degrading microbes and plant root can penetrate into the soil, able to grow and finally able to degrade hidden PAHs (Kuppusamy et al., 2017). Earthworms also remove PAHs from the soil by either dermal absorption or intestinal digestion that biotransform or biodegrade into harmless compounds (Sinha et al., 2008). Benefits of vermiremediation include improvement of physical/biological soil quality, excretion of nutritive constituents as vermicasts, and proliferation of beneficial soil microorganisms (Rorat et al., 2017). Earthworms reproduce speedily using less or no energy, which possibly enhance PAH removal in a short time duration, proving vermiremediation to be very cost-effective, eco-friendly, and sustainable (Sinha et al., 2008). The addition of earthworms Eisenia andrei in sewage sludge bioreactor after precomposting had led to higher PAH removal $(86,58$, and $62 \%$ under three different pre-composting processes) after 5 weeks (Rorat et al., 2017). The only drawback of vermiremediation is that it is applicable for low and medium polluted sites, where earthworms are able to survive and grow (Kuppusamy et al., 2017).

\section{Factors Affecting Polycyclic Aromatic Hydrocarbon Bioremediation}

Polycyclic aromatic hydrocarbon bioremediation depends on many factors, including $\mathrm{PAH}$ properties, polluted material properties, environmental parameters, and microbial ecology. Abiotic and biotic factors such as temperature, $\mathrm{pH}$, salinity, humidity, nutrient availability, oxygen level, pollutants bioavailability, pollutants concentration, native microflora availability and their degradation capability, microbial substrate specificity, pre exposure of pollutants, production or addition of biosurfactants, and presence of other carbon sources can apparently diverge from site to site that can influence the process of bioremediation (Mohan et al., 2006; Ukiwe et al., 2013; Ghosal et al., 2016). Many factors are interconnected, for example, temperature variation affects $\mathrm{PAH}$ solubility and microbial activity (Mehetre et al., 2019). Texture, permeability, moisture content, density, porosity, nutrient quality, pollution aging, organic matter content, microbial density, and microbial diversity of soil/sediment are important factors in the case of soil PAH bioremediation (Chen et al., 2015). The efficiency of microbial remediation is affected by the distribution of pollutants, distribution of microbes, and metabolic capability of microbes (Kong et al., 2018).

The structure of PAHs is one of the deciding factors for selection of degradation methods. Angular arrangement is thermodynamically the most stable configuration of PAHs, but their bay regions are prone to enzymatic degradation; this is the reason for more biodegradation of angular structures than linear and clustered structures. Whereas linear and clustered PAHs are degraded rapidly by photooxidation and chemical oxidation (Abdel-Shafy and Mansour, 2016; Peluffo et al., 2018). As per Clar's resonance structure rule, aromaticity of PAHs strongly depends on the number of aromatic $\pi$-sextets. Aromatic $\pi$-sextet rings are more stable, whereas less aromatic rings (rings with minimum number of double bonds) are more reactive for photo-and chemical oxidation. For example, both angular $\mathrm{PAH}$ phenanthrene and clustered $\mathrm{PAH}$ pyrene have two aromatic $\pi$-sextet rings, but phenanthrene has just one and pyrene has two less aromatic rings.

Hence, pyrene degradation is more rapid than phenanthrene by photo/chemical oxidation. This phenomenon is explained by the study of Peluffo et al. (2018), where they reported 
higher degradation of pyrene ( $96 \%$ of $2,800 \mathrm{mg} \cdot \mathrm{kg}^{-1}$ ) than phenanthrene $\left(91 \%\right.$ of $\left.1,200 \mathrm{mg} \cdot \mathrm{kg}^{-1}\right)$ in the batch reactor of aged polluted soil at room temperature within 7 days by thermal $\left(65^{\circ} \mathrm{C}\right.$ for $\left.6 \mathrm{~h}\right)$-activated persulfate oxidation. Biache et al. (2017) proved that $\mathrm{PAH}$ bioremediation was highly dependent on soil type using bioslurry experiments at $28^{\circ} \mathrm{C}$ in dark and under continuous shaking $(120 \mathrm{rpm})$ with three different types of soil, i.e., former gas plant site soil (76\% degradation), former coking plant site soil (34\% degradation), and active wood-treating facility site soil (98\% degradation).

\section{Insights From -Omics Approaches Used for Elucidating Polycyclic Aromatic Hydrocarbon Bioremediation}

The studies of PAH-degrading microbial community, degrading genes, regulatory genes of degradation, enzyme systems, intermediates and final products of degradation pathways, and the study of indigenous microbial diversity at polluted sites are associated with an actual understanding of $\mathrm{PAH}$ bioremediation. Ideal and successful PAH bioremediation design can be strategized based on knowledge of indigenous microbes at polluted sites, their metabolic versatility, and their adaptations toward environmental harsh conditions (Malla et al., 2018). Unfortunately, this particular knowledge is not available easily, which can be gained by the "genomic era," including culture-independent approaches such as metagenomics (eDNA), metatranscriptomics (eRNA), metaproteomics (eProteins), and metabolomics (eMetabolites) (Desai et al., 2010; El Amrani et al., 2015). The presence of only 0.1$1.0 \%$ culturable microbes in the environment is a major drawback of traditional culture-dependent approaches. The remaining 99.0-99.9\% are unculturable microbes due to the lack of knowledge of their culturing conditions (Daniel, 2005; Quintero and Zafra, 2016). So, traditional methods limit the complete evaluation of microbial diversity and their functional potential, which can be overcome by metagenomic methods. Advances in next-generation sequencing and associated in silico analysis enable addressing metagenomic studies (Quintero and Zafra, 2016).

Metagenomic methods have two distinct approaches: sequence-based and function-based. Sequence-based metagenomic approach is useful to investigate the actual microbial diversity, microbial evolution, microbial interactions, complete degradation pathways, degrading genes, etc. The function-based metagenomic approach is useful for discovering of novel degradative genes (Malla et al., 2018). The functional capabilities of microbial communities can be analyzed at different levels, i.e., metatranscriptomics, metaproteomics, and metabolomics. Metatranscriptomics decipher mRNA profile for up/downregulation of degradative microbes and related genes. Metaproteomics track pollutants induced by proteins by degrading microbes. Metabolomics analyze metabolites generated by degradative microbes to cope up with pollutants (Desai et al., 2010). Metatranscriptomic approaches are not only useful for predicting the functions of abundant members but also are useful for predicting the functions of low-abundance members that comprise as little as $0.05 \%$ of the total cell population (Helbling et al., 2012).

Amplicon-based metagenomics by identifying correct microbial taxa as targets help to develop a sustainable frame for precision bioremediation in soil or sediment. Microbial taxa having the pollutant degradation ability and survival capacity at a polluted site can act as biostimulants, whereas microbial taxa having characteristics such as the abundant presence at site, fast growth, easy cultivation, non-pathogenicity, and able to survive and metabolize high concentrations of pollutants can be utilized for bioaugmentation (Redfern et al., 2019). Redfern et al. (2019) identified Geobacter spp. as biostimulation targets, whereas Mycobacterium spp. and Sphingomonads spp. are bioaugmentation targets for creosote-polluted soil using a metagenomic approach along with the Spearman rank correlation statistics (non-parametric test). According to correlation statistics, all positively correlated taxa can be utilized in $\mathrm{PAH}$ bioremediation as they are resistant to PAHs and, conversely, negatively correlated taxa are sensitive to PAHs (Redfern et al., 2019). Muangchinda et al. (2018) reported changes in the bacterial communities between original seawater and mixed PAH-degrading consortium SWO (developed from the same sea water) using high-throughput 16S rRNA gene sequencing. They found an increased proportion of Proteobacteria and decreased proportion of Bacteroidetes in consortium SWO along with lower Shannon and Simpson indices. Microbial diversity of the diesel-degrading consortium and key genes for degrading enzymes were studied by 16S rRNA amplicon and shotgun metagenome sequencing, respectively (García-Sánchez et al., 2018).

Zhang et al. (2019) performed interesting research using artificially pyrene-polluted sediment, which covered studies of bacterial synergism, their metabolic profile under pyrene stress, construction of metagenome-assembled genomes (MAGs), and coordination of aromatic hydrocarbon-degrading genes with various metabolic pathways (such as carbohydrate metabolism, ATP synthesis, carbon fixation, nitrogen metabolism, sulfate metabolism, acylglycerol degradation, and Calvin cycle) (Zhang et al., 2019). They found dominance of uncultivable genera ZD0117 and unclassified Alteromonadaceae belonging to Gammaproteobacteria after 30 days of pyrene stress, suggesting their important role in degradation. They constructed a total of 56 MAGs belonging to Gamma- and Alphaproteobacteria; many of them were uncultivable and unclassified, among which 20 MAGs showed the presence of $\mathrm{PAH}$ degradation genes (Zhang et al., 2019).

Specific PAH-degrading genes, for example, $\mathrm{PAH}$ ring hydroxylating dioxygenases (RHDs), can be utilized as biomarkers for characterization of $\mathrm{PAH}$-degrading microbes. Gene-targeted metagenomics approach based on PAH RHDs was proven suitable and promising for $\mathrm{PAH}$-degrading bacterial diversity study in oil-polluted soil and mangrove sediment (Liang et al., 2019). Storey et al. (2018) noticed 10,000-fold higher abundance of PAH RHD genes in phenanthrene-polluted soil as compared to unpolluted soil. In a nutshell, omics techniques are imperative for monitoring the effectiveness and status 
of bioremediation. Omics techniques answer the important questions related to the fate of augmented and indigenous degrading microorganisms, enumeration of degrading genes, and the role of uncultivable microorganisms, etc. (Quintero and Zafra, 2016). However, omics approaches are still relatively unexplored and practically limited for $\mathrm{PAH}$ bioremediation strategies due to hurdles in omics massive data handling and interpretations.

\section{Considerable Constraints During Polycyclic Aromatic Hydrocarbon Bioremediation}

The site assessment and condition optimization for method suitability and satisfactory results are always required for the implementation of bioremediation strategies. Lack of endorsed criteria for evaluating the failure and success of field-scale bioremediation is a matter that requires attention. Operational difficulties arise during implementation of $\mathrm{PAH}$ bioremediation strategies from bench to pilot and finally to the field scale, since the lab-scale experiments do not inevitably accurately reflect site-specific applications. Other considerable constraints for successful bioremediation include remediation cost, inappropriate objectives, lack of time management, lack of maintenance and monitoring, etc. Most of the bioremediation approaches used previously have placed more emphasis on removal of parent pollutants rather than measurement of toxicity reduction of the metabolites generated after $\mathrm{PAH}$ biodegradation. The R\&D funding and commercial investments for bioremediation processes are lagging far behind than other industrial sectors, as PAH bioremediation does not produce high value-added marketable by-products along with degradation. Laws and regulations related to the environment limit the implementation of some bioremediation approaches such as the use of genetically engineered microorganisms.

\section{NEW DEVELOPMENTS AND EMERGING MULTI-PROCESS POLYCYCLIC AROMATIC HYDROCARBON REMEDIATION APPROACHES}

Nanoparticle (NP)-based eco-engineered bioremediation strategy signifies key emerging research fields to deal with pollutants like PAHs from various matrices such as soil, sediment, surface water, and groundwater. The development in NPs demands additional improvement like enhancement of their characteristics through modification in surface properties called "functionalized nanoparticles," which are able to play multifunctional roles in the bioremediation field (Basak et al., 2020). Bionano-remediation employs a large range of biomolecules as functionalizing agents, mainly enzymes, proteins, DNA, humic acids, and biosurfactants, for remediating many petroleum hydrocarbons including PAHs (Basak et al., 2020). The added advantages of NPs are efficient reactivity and offering higher surface area due to their nano-scale size. The system of (bio)functionalized NPs has nano-adsorptive and catalytic degrading properties in order to remove PAHs from the polluted environment (Basak et al., 2020). Wang et al. (2015) demonstrated benzo(a)pyrene degradation from polluted surface and subsurface soil using silica NPs coated with zwitterionic lipid (1,2-dimyristoylsn-glycero-3-phosphocholine) bilayers.

The lipid-based (bio)functionalized silica NPs provided two methods of remediation: (1) sequestration of benzo(a)pyrene by adsorption and (2) providing colloidal stability necessary for transport to the polluted source (Wang et al., 2015). Shanker et al. (2017) have synthesized iron hexacyanoferrate (FeHCF) NPs (10-60 nm size) of various shapes (hexagonal, rod, and spherical) using plant origin biosurfactant (saponins) extracted from Sapindus mukorossi and water as solvent. The properties such as ion exchange, photomagneticity, and electrochromicity encourage the use of FeHCFs as NPs. Under optimized experimental system ( $\mathrm{pH} 7$, catalyst $25 \mathrm{mg}$, PAHs $50 \mathrm{mg} / \mathrm{L}$, and solar radiation), anthracene and phenanthrene degradation was 80-90\%, while fluorene, chrysene, and benzo(a)pyrene degradation was $70-80 \%$ in water and soil. Moreover, all PAHs were converted into low-molecular weight non-toxic metabolites after treatment. FeHCF NPs acted as good adsorbents and photocatalysts in the study by Shanker et al. (2017).

Even though the abovementioned physical, chemical, and biological methods are capable of PAH removal, their limitations can be overcome using two or more integrated methods (Kuppusamy et al., 2017). Integrated methods are efficient and advantageous approaches, especially for HMW PAH degradation (Ukiwe et al., 2013; Peng X. et al., 2018). Integrated degradation methods resolve the dead-end product problems and clean the environment completely with less time (Ukiwe et al., 2013). Emerging multi-process/integrated methods for PAH bioremediation include physical-biological coupled remediation (Mao et al., 2017; Cameselle and Gouveia, 2019), chemicalbiological coupled remediation (Xu et al., 2019; Gou et al., 2020), multi-biological remediation (Liu et al., 2019; Zeneli et al., 2019), and combination of all three physical-chemicalbiological coupled remediation (Wang et al., 2019). Figure 2 summarizes various integrated approaches currently used in $\mathrm{PAH}$ remediation.

Mao et al. (2017) have developed ex situ surfactantaided soil washing method using tea saponin $(7.5 \mathrm{~g} / \mathrm{L})$ and soybean oil $(15.0 \mathrm{ml} / \mathrm{L})$ for $\mathrm{PAH}$ - and heavy metal-polluted cooking plant soil. Polluted $1 \mathrm{~kg}$ soil was washed with $5 \mathrm{~L}$ washing solvent in stirring tank at $50^{\circ} \mathrm{C}$ along with ultrasonication, and two washing cycles removed 98.2, 96.4, 92.3, 96.3, 94.1, and $89.4 \%$ of 3-ring PAHs, 4-ring PAHs, 5-6ring $\mathrm{PAHs}$, total $\mathrm{PAHs}$, cadmium, and nickel, respectively. They have also reported good efficiency of recovered washing solvent. Further, alkaline solution-based precipitation and inoculation of PAH-degrading Sphingobium sp. PHE9 removed 92.6 to $98.4 \%$ PAHs from washing solvents of the first and second cycles.

Cameselle and Gouveia (2019) devised an electric current-assisted phytoremediation system for remediation of PAHs and heavy metals from contaminated soil. Fast germinating and growing capabilities of plant species 


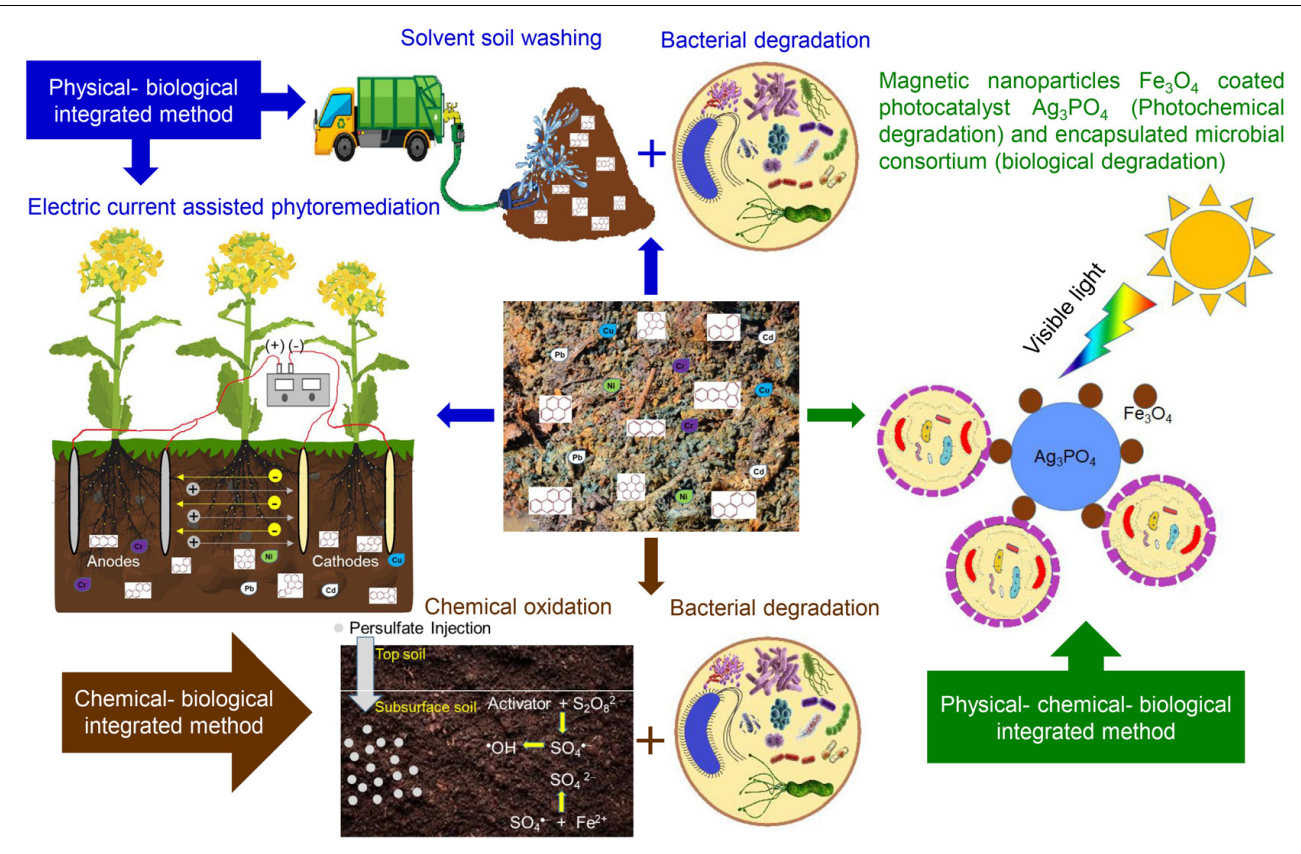

FIGURE 2 | Various integrated approaches used in polycyclic aromatic hydrocarbon (PAH) remediation processes.

Brassica rapa were proven effective among 14 different plant species along with alternating current (AC) from the parallel electrodes. The electric current in the field improved the bioavailability of nutriments and pollutants and favored the growth of plant and rhizosphere bacteria and their remediation ability. The integrated physical and biological methods were proven suitable for the management of mixed polluted soil (Mao et al., 2017; Cameselle and Gouveia, 2019).

In field-scale $\mathrm{PAH}$ remediation, chemical oxidation alone may require multiple applications for complete removal of PAHs, which increases the operational cost, and soil quality and soil microorganisms get negatively affected. Similarly, bioremediation alone is not able to degrade HMW PAHs (5-6 rings) from aged and chronically polluted soil due to strong adsorption of HMW PAHs with soil particle. Hence, an integrated chemical and biological method is a costcompetitive and preferable approach, which is able to overcome limitations of either method (Gou et al., 2020). Pre-chemical oxidation reduces soil microbial diversity and richness, so that subsequent $\mathrm{PAH}$ biodegradation may be affected, which can be overcome by optimizing the concentration of the chemical oxidant.

Gou et al. (2020) investigated the potential of integrated chemical oxidation using sodium persulfate and anoxic biodegradation in subsurface aged PAH-polluted soil. They monitored the effects of different persulfate dosages (1 and $3 \% \mathrm{w} / \mathrm{w}$ ) on abundance and community of soil bacteria and optimized $1 \%$ as the suitable dosage. After 180 days of incubation, the integrated approach showed significantly enhanced removal of 3 - and 4-ring PAHs from the polluted subsurface soil as compared to chemical oxidation alone and anoxic biodegradation alone. Removal of most of the 5- and 6-ring PAHs occurred by chemical oxidation in the study by Gou et al. (2020). Xu et al. (2019) found that chemical oxidation of benzo(a)pyrene in polluted soil by $20 \mathrm{mmol} / \mathrm{L}$ iron-activated sodium persulfate and $10 \mathrm{mmol} / \mathrm{L}$ potassium permanganate further enhanced PAH biodegradation up to 98.7 and $84.2 \%$ within 60 days.

Liu et al., 2019 have applied two biological approaches together for $\mathrm{PAH}$ degradation in aged polluted soil, i.e., bioaugmentation with bacteria Paracoccus sp. LXC and biostimulation with humic acid and spent mushroom substrate and have achieved 56.5\% PAH degradation. Similarly, multi-process bioaugmentation-biostimulation methods were found to degrade 52 and $87 \%$ of total petroleum hydrocarbons and PAHs in refinery solid wastes after 80 days of incubation, which were high as compared to biostimulation alone (47 and $59 \%$ ) and natural attenuation (37 and 42\%) (Zeneli et al., 2019).

Wang et al. (2019) have also developed a novel integrated method in which photochemical degradation and microbial degradation were coupled for multi-PAH remediation in polluted soil. $\mathrm{Ag}_{3} \mathrm{PO}_{4}$ visible light-responsive photocatalyst was attached to $\mathrm{Fe}_{3} \mathrm{O}_{4}$ magnetic NPs and formed active conjugates responsible for HMW PAH degradation in response to photooxidation. Microbial consortium (MC) was immobilized in microcapsules (MI), which was responsible for LMW PAH degradation due to microbial activities. The active photocatalyst conjugate $\mathrm{Ag}_{3} \mathrm{PO}_{4} @ \mathrm{Fe}_{3} \mathrm{O}_{4}$ was anchored on the membrane of $\mathrm{MI}$ embedded with MC, which was called MI-MC-photocatalyst compound system (MCS). MCSs have removed $944.1 \mathrm{mg} / \mathrm{kg}$ of PAHs (94.4\%) within 30 days under visible light at $25^{\circ} \mathrm{C}$ along with improvement in soil microbial ecology and decreased soil 
eco-toxicity, which was confirmed by soil seed germinability (Wang et al., 2019).

\section{SIGNIFICANCE OF POLYCYCLIC AROMATIC HYDROCARBON REMEDIATION THROUGH VALUE- ADDED BY-PRODUCT GENERATION}

In the current scenario, most of the research studies are drawing attention toward the applicative aspects of by-product generation during PAH biodegradation, e.g., biogas production, bioelectricity generation, biosurfactant production, and extracellular polymeric substance (EPS) production (Jia et al., 2016; Yu et al., 2017; Tripathi et al., 2019; Bianco et al., 2020). Bianco et al. (2020) demonstrated anaerobic degradation of phenanthrene, anthracene, fluoranthene, and pyrene in polluted marine sediments by a biostimulation approach. They supplemented fresh organic residues of municipal solid waste, digestate, and several other nutrients as the biostimulants that are able to degrade a maximum of $55 \%$ of total PAHs after 120 days, along with a maximum of $80 \mathrm{ml} . \mathrm{gVS}^{-1}$ of bio hydrogen production from 3 to 30 days under acidogenic conditions and 140 ml.gVS ${ }^{-1}$ of bio methane production from 50 to 120 days under methanogenic conditions. Bio methane production showed an increasing trend even after 120 days, suggesting the possibility of higher yield upon prolonged biostimulation (Bianco et al., 2020).

Sayara et al. (2010) developed a composting-mediated PAH degradation approach in contaminated soil under strict anaerobic methanogenic conditions and reported 91\% PAH degradation along with $117.9 \mathrm{~L}$ of biogas production after 50 days of incubation per kilogram of total solids utilized. Biohydrogen is recognized as a sustainable energy option for fuel cell technology to produce electricity, which minimizes environmental pollution as compared to conventional fuel cell technology. Biohydrogenbased fuel cells can have wide applications like vehicles, home electrical machineries, and other portable batteries (Rahman et al., 2016). Biogas that is generated as a by-product of anaerobic PAH degradation is recognized as a renewable energy source. Biogas in the form of methane is an alternative fuel substitute of fossil fuels and may have applications in energy production due to its capability to generate heat and power (Amin et al., 2011). The applications of biomethane include usage as fuel for stoves/boilers, fuel for engines and gas turbines for producing electricity, fuel for vehicles, and fuel for fuel cells (Sun et al., 2015).

The microbial bioelectrochemical systems contain single or series of chambers in which anode- and cathode-mediated redox reactions are catalyzed particularly by microbes due to activities of electrogenic biocatalysts (Allen and Bennetto, 1993). Electrons generated from the oxidation of organic matter by the microbial action are transferred to the anode via conductive material from the cathode, which produce electric current, and electrons at the cathode can be consumed in biotic and abiotic reduction reactions (Logan et al., 2006). In this manner, microorganisms produce bioelectricity during degradation, which can be utilized to fulfill electricity requirements for our resource-intensive society (Kiely et al., 2011).

The biocatalytic reactions improve $\mathrm{PAH}$ degradation by providing alternative electron acceptors (Chandrasekhar and Mohan, 2012). Yu et al. (2017) reported degradation of anthracene (54\%), phenanthrene (43\%), and pyrene (27\%) in contaminated soil coupled with $12.1 \mathrm{mWm}^{-2}$ of power generation by associated soil microbial fuel cells (MFCs). Sherafatmand and Ng (2015) developed sediment MFCs, which were able to work in both aerobic and anaerobic PAH degradation conditions. The degradation of naphthalene, acenaphthene, and phenanthrene was 42,31 , and $36 \%$ along with $6.0 \mathrm{mWm}^{-2}$ of power generation under aerobic conditions, whereas degradation was 77,53 , and $37 \%$ along with $3.6 \mathrm{mWm}^{-2}$ of power generation under anaerobic conditions, respectively (Sherafatmand and Ng, 2015).

Polycyclic aromatic hydrocarbon degradation is also involved in the production of prominently applicable by-products particularly biosurfactants and EPSs. Biosurfactants are amphiphilic biomolecules mainly produced by a wide range of PAH degraders in order to enhance the bioavailability of PAHs and hence accelerate the degradation efficiency (Tripathi et al., 2019). The researchers have reported diverse forms of biosurfactants, mainly rhamnolipids, lipopeptides, glycoproteins, and surfactins from different PAH degraders (Nie et al., 2010; Ibrar and Zhang, 2020; Kotoky and Pandey, 2020; Tao et al., 2020). The chemically diverse biosurfactants are known as greener biomolecules, which have tremendous applicative aspects apart from field-scale bioremediation, including food, agricultural, oil, cosmetic, and pharmaceutical industries (Farias et al., 2019; Jimoh and Lin, 2019). Their multiple worthwhile properties such as higher foaming, low critical micelle concentrations, and high selective estimable surface activity make them excellent dispersing agents, emulsifiers, and promising substitutes of chemically synthesized surfactants (Jimoh and Lin, 2019).

Farias et al. (2019) formulated six mouthwashes using peppermint essential oil, chitosan, and biosurfactants extracted from Pseudomonas aeruginosa UCP 0992, Bacillus cereus UCP 1615, and Candida bombicola URM 3718 for the control of cariogenic oral microorganisms. Validated results revealed that potential application of biosurfactants in mouthwash preparations is safe and a feasible alternative (Farias et al., 2019). Biosurfactants are also applicable for the remediation of heavy metals from contaminated environments apart from hydrocarbon bioremediation (Ravindran et al., 2020). Several researchers demonstrated application of biosurfactants such as rhamnolipid, lipopeptide, and glycoprotein in microbe-enhanced oil recovery (Arora et al., 2019; Purwasena et al., 2019).

Polycyclic aromatic hydrocarbon degraders secrete EPSs for functioning of various vital physiological processes, which include water-retentive protective layer formation around bacterial cell, bacterial adherence to the surfaces, cell aggregation, microbial floc and biofilm matrix establishment, and resistance toward heavy metals (Flemming and Wingender, 2010; Hong et al., 2013). EPSs are produced in the form of exopolysaccharide, 
alginate, dextran, gellan, pullulan, xanthan gum, cellulose, pectin, starch, mutan, and levan by a diverse range of microorganisms (More et al., 2014). Such structurally and chemically diverse by-products (i.e., EPSs) of PAH degradation have promising applications in multiple areas such as pharmaceutics, healthcare, food, and agriculture due to their gelling, stabilizing, thickening, and emulsifying characteristics (Moscovici, 2015; Wang et al., 2018). Additionally, EPSs are also linked with the remediation of a wide range of pollutants, mainly toxic heavy metals, hydrocarbons, and inorganic pollutants present in wastewater and soil (Shojaipour et al., 2020). The research studies have also demonstrated the role of exopolysaccharides in microbeenhanced oil recovery (Li et al., 2017).

\section{PERSPECTIVE, FUTURE OUTLOOK, AND CONCLUSION}

The pollution of bio-toxic PAHs originating from various sources discussed above has severely affected pristine environments and human health. As discussed in this review, considerable progress has been made in developing various technologies and strategies for environmental remediation of $\mathrm{PAH}$ pollution. However, many challenges remain unresolved, and site remediation of PAHs is still a formidable task. Laboratory- and pilot/reactorscale studies have provided ample evidence, detailed and distinct mechanistic insights into LMW and HMW PAH degradation. LMW PAHs were found to be comparatively easy to degrade, while most of the carcinogenic PAHs are HWM PAHs with more compact rings and their degradation is very difficult. Moreover, the accumulated evidence by several years of research has suggested that the replications of lab-scale results into field-scale applications are inadequate. From the scientific literature assessed in this review, it was apparent that the bioremediation approaches provide a plausible solution for $\mathrm{PAH}$ remediation. There is a new trend in rejuvenating the conventional treatment systems such as phytoremediation, landfarming, and composting for PAH treatment. The synergetic interactions between microorganisms and plants have been well exploited for in situ bioremediation of PAHs. Emerging integrated approaches such as eco-engineered bioremediation of PAH using bionanoparticles, bioaugmentation-biostimulation, photochemical degradation followed by microbial degradation,

\section{REFERENCES}

Abdel-Shafy, H. I., and Mansour, M. S. (2016). A review on polycyclic aromatic hydrocarbons: source, environmental impact, effect on human health and remediation. Egypt. J. Pet. 25, 107-123. doi: 10.1016/j.ejpe.2015.03.011

Adeniji, A., Okoh, O., and Okoh, A. (2019). Levels of polycyclic aromatic hydrocarbons in the water and sediment of Buffalo River Estuary, South Africa and their health risk assessment. Arch. Environ. Con. Tox. 76, 657-669. doi: 10.1007/s00244-019-00617-w

Agnello, A. C., Bagard, M., van Hullebusch, E. D., Esposito, G., and Huguenot, D. (2016). Comparative bioremediation of heavy metals and petroleum hydrocarbons co-contaminated soil by natural attenuation, phytoremediation, bioaugmentation and bioaugmentation-assisted phytoremediation. Sci. Total Environ. 563, 693-703. doi: 10.1016/j.scitotenv.2015.10.061 immobilization of microbial consortium in microcapsules, etc., have greatly enhanced efficiency for remediation of $\mathrm{PAH}$ contamination in the environment.

Understanding and recognizing the dynamics of $\mathrm{PAH}$ degradation under soil and marine environment are major problems, which need to be addressed in future research. Under the soil ecosystem, the released PAHs often get entrapped in black-clayish-carbon particles and in coal tar, which significantly reduce their bioavailability. Thus, it is one of the major bottlenecks for successful PAH bioremediation. The optimal role of dissolved oxygen concentration, available nutrient, co-contaminants (e.g., heavy metals, phenolics, etc.), and abiotic parameters decides the fate of $\mathrm{PAH}$ remediation approaches. Since the natural environment is an interactive and interdependent system for niche and nutrient cycling by microbial communities, an understanding of the synergistic hydrocarbon degradation mechanisms is required for proper implementation and scale-up of in situ biostimulation and bioaugmentation approaches. Notably, the newer developments in the generation of value-added by-products (e.g., biofuels, biosurfactants, and bioenergy) during $\mathrm{PAH}$ remediation are a pragmatic approach, which need to be explored in future research.

\section{AUTHOR CONTRIBUTIONS}

$\mathrm{DM}$ and KJ conceived the initial theme and concept for the review. AP carried out the literature survey, translated the concept, and wrote the manuscript. KJ and SS contributed in writing parts of the manuscript. CD and DM comprehensively edited, revised, and proofread the manuscript. All authors read and approved the final manuscript.

\section{FUNDING AND ACKNOWLEDGMENTS}

The authors acknowledge the Department of Biotechnology (DBT), Ministry of Science and Technology, Government of India, New Delhi, for financial support (BT/01/CEIB/09/V/05). AP is thankful to the Council of Scientific and Industrial Research (CSIR) for providing Senior Research Fellowship [09/157(0054)2K18 EMR-1].

Agrawal, N., Verma, P., and Shahi, S. K. (2018). Degradation of polycyclic aromatic hydrocarbons (phenanthrene and pyrene) by the ligninolytic fungi Ganoderma lucidum isolated from the hardwood stump. Bioresour. Bioprocess. 5, 1-9. doi: $10.1155 / 2012 / 243217$

Allen, R., and Bennetto, H. (1993). Microbial fuel cells: electricity production from carbohydrates. Appl. Biochem. Biotechnol. 39, 27-40. doi: 10.1007/bf02918975

Al-Mailem, D. M., Al-Deieg, M., Eliyas, M., and Radwan, S. S. (2017). Biostimulation of indigenous microorganisms for bioremediation of oily hypersaline microcosms from the Arabian Gulf Kuwaiti coasts. J. Environ. Manage. 193, 576-583. doi: 10.1016/j.jenvman.2017. 02.054

Amin, A. M., Croiset, E., and Epling, W. (2011). Review of methane catalytic cracking for hydrogen production. Int. J. Hydrog. Energy 36, 2904-2935. doi: 10.1016/j.ijhydene.2010.11.035 
Arias, A. H., Souissi, A., Glippa, O., Roussin, M., Dumoulin, D., Net, S., et al. (2017). Removal and biodegradation of phenanthrene, fluoranthene and pyrene by the marine algae Rhodomonas baltica enriched from North Atlantic Coasts. B. Environ. Contam. Tox. 98, 392-399. doi: 10.1007/s00128-016-1967-4

Arora, P., Kshirsagar, P., Rana, D. P., and Dhakephalkar, P. (2019). Hyperthermophilic Clostridium sp. N-4 produced a glycoprotein biosurfactant that enhanced recovery of residual oil at $96^{\circ} \mathrm{C}$ in lab studies. Colloids Surf. B Biointerf. 182:110372. doi: 10.1016/j.colsurfb.2019.110372

Arulazhagan, P., Al-Shekri, K., Huda, Q., Godon, J.-J., Basahi, J. M., and Jeyakumar, D. (2017). Biodegradation of polycyclic aromatic hydrocarbons by an acidophilic Stenotrophomonas maltophilia strain AJH1 isolated from a mineral mining site in Saudi Arabia. Extremophiles 21, 163-174. doi: 10.1007/ s00792-016-0892-0

Aydin, S., Karaçay, H. A., Shahi, A., Gökçe, S., Ince, B., and Ince, O. (2017). Aerobic and anaerobic fungal metabolism and Omics insights for increasing polycyclic aromatic hydrocarbons biodegradation. Fungal Biol. Rev. 31, 61-72. doi: 10.1016/j.fbr.2016.12.001

Baldantoni, D., Morelli, R., Bellino, A., Prati, M. V., Alfani, A., and De Nicola, F. (2017). Anthracene and benzo (a) pyrene degradation in soil is favoured by compost amendment: perspectives for a bioremediation approach. J. Hazard. Mater. 339, 395-400. doi: 10.1016/j.jhazmat.2017.06.043

Basak, G., Hazra, C., and Sen, R. (2020). Biofunctionalized nanomaterials for in situ clean-up of hydrocarbon contamination: a quantum jump in global bioremediation research. J. Environ. Manage. 256, 1-20.

Biache, C., Ouali, S., Cébron, A., Lorgeoux, C., Colombano, S., and Faure, P. (2017). Bioremediation of PAH-contamined soils: consequences on formation and degradation of polar-polycyclic aromatic compounds and microbial community abundance. J. Hazard. Mater. 329, 1-10. doi: 10.1016/j.jhazmat. 2017.01.026

Bianco, F., Race, M., Papirio, S., and Esposito, G. (2020). Removal of polycyclic aromatic hydrocarbons during anaerobic biostimulation of marine sediments. Sci. Total Environ. 709, 136-141.

Birolli, W. G., Santos, D. D. A., Alvarenga, N., Garcia, A. C., Romão, L. P., and Porto, A. L. (2018). Biodegradation of anthracene and several PAHs by the marine-derived fungus Cladosporium sp. CBMAI 1237. Mar. Pollut. Bull. 129, 525-533. doi: 10.1016/j.marpolbul.2017.10.023

Bisht, S., Pandey, P., Bhargava, B., Sharma, S., Kumar, V., and Sharma, K. D. (2015). Bioremediation of polyaromatic hydrocarbons (PAHs) using rhizosphere technology. Braz. J. Microbiol. 46, 7-21. doi: 10.1590/s1517-838246120131354

Bojes, H. K., and Pope, P. G. (2007). Characterization of EPA's 16 priority pollutant polycyclic aromatic hydrocarbons (PAHs) in tank bottom solids and associated contaminated soils at oil exploration and production sites in Texas. Regul. Toxicol. Pharm. 47, 288-295. doi: 10.1016/j.yrtph.2006.11.007

Bolden, A. L., Rochester, J. R., Schultz, K., and Kwiatkowski, C. F. (2017). Polycyclic aromatic hydrocarbons and female reproductive health: a scoping review. Reprod. Toxicol. 73, 61-74. doi: 10.1016/j.reprotox.2017.07.012

Bonfá, M. R., Grossman, M. J., Mellado, E., and Durrant, L. R. (2011). Biodegradation of aromatic hydrocarbons by Haloarchaea and their use for the reduction of the chemical oxygen demand of hypersaline petroleum produced water. Chemosphere 84, 1671-1676. doi: 10.1016/j.chemosphere.2011.05.005

Brandt, M., and Einhenkel-Arle, D. (2016). Polycyclic Aromatic Hydrocarbons Harmful to the Environment! Toxic! Inevitable? German Environ. Agency 1-24.

Burchiel, S. W., and Gao, J. (2014). "Polycyclic aromatic hydrocarbons and the immune system," in Encyclopedia Immunotoxicology, ed H-W. Vohr (Berlin: Springer), doi: 10.1007/978-3-642-27786-3_1192-4

Burchiel, S. W., and Luster, M. I. (2001). Signaling by environmental polycyclic aromatic hydrocarbons in human lymphocytes. Clin. Immunol. 98, 2-10. doi: 10.1006/clim.2000.4934

Cameselle, C., and Gouveia, S. (2019). Phytoremediation of mixed contaminated soil enhanced with electric current. J. Hazard. Mater. 361, 95-102. doi: 10.1016/ j.jhazmat.2018.08.062

Cerniglia, C., and Sutherland, J. (2010). "Degradation of polycyclic aromatic hydrocarbons by fungi," in Handbook of Hydrocarbon and Lipid Microbiology, eds K. N. Timmis, J. R. van der Meer, T. J. McGenity, and V. de Lorenzo (Berlin: Springer Science \& Business Media). doi: 10.1007/978-981-10-6775-4_8

Chan, S. M. N., Luan, T., Wong, M. H., and Tam, N. F. Y. (2006). Removal and biodegradation of polycyclic aromatic hydrocarbons by Selenastrum capricornutum. Environ. Toxicol. Chem. 25, 1772-1779. doi: 10.1897/05-354r.1
Chandrasekhar, K., and Mohan, S. V. (2012). Bio-electrochemical remediation of real field petroleum sludge as an electron donor with simultaneous power generation facilitates biotransformation of PAH: effect of substrate concentration. Bioresour. Technol. 110, 517-525. doi: 10.1016/j.biortech.2012. 01.128

Chen, B., Huang, J., Yuan, K., Lin, L., Wang, X., Yang, L., et al. (2016). Direct evidences on bacterial growth pattern regulating pyrene degradation pathway and genotypic dioxygenase expression. Mar. Pollut. Bull. 105, 73-80. doi: 10.1016/j.marpolbul.2016.02.054

Chen, M., Xu, P., Zeng, G., Yang, C., Huang, D., and Zhang, J. (2015). Bioremediation of soils contaminated with polycyclic aromatic hydrocarbons, petroleum, pesticides, chlorophenols and heavy metals by composting: applications, microbes and future research needs. Biotechnol. Adv. 33, 745-755. doi: 10.1016/j.biotechadv.2015.05.003

Chikere, C. B., Azubuike, C. C., and Fubara, E. M. (2017). Shift in microbial group during remediation by enhanced natural attenuation (RENA) of a crude oil-impacted soil: a case study of Ikarama Community. Bayelsa, Nigeria. 3 Biotech 7, 1-11.

Cook, R. L., and Hesterberg, D. (2013). Comparison of trees and grasses for rhizoremediation of petroleum hydrocarbons. Int. J. Phytoremediat. 15, 844860. doi: $10.1080 / 15226514.2012 .760518$

Daniel, R. (2005). The metagenomics of soil. Nat. Rev. Microbiol. 3, 470-478.

Das, N., and Das, D. (2015). Strategies for remediation of polycyclic aromatic hydrocarbons from contaminated soil-an overview. J. Crit. Rev. 2, 20-25.

Dastgheib, S. M. M., Amoozegar, M. A., Khajeh, K., Shavandi, M., and Ventosa, A. (2012). Biodegradation of polycyclic aromatic hydrocarbons by a halophilic microbial consortium. Appl. Microbiol. Biotechnol. 95, 789-798. doi: 10.1007/ s00253-011-3706-4

De Llasera, M. P. G., de Jesús Olmos-Espejel, J., Díaz-Flores, G., and MontañoMontiel, A. (2016). Biodegradation of benzo (a) pyrene by two freshwater microalgae Selenastrum capricornutum and Scenedesmus acutus: a comparative study useful for bioremediation. Environ. Sci. Pollut. Res. 23, 3365-3375. doi: 10.1007/s11356-015-5576-2

Desai, C., Pathak, H., and Madamwar, D. (2010). Advances in molecular and “-omics" technologies to gauge microbial communities and bioremediation at xenobiotic/anthropogen contaminated sites. Bioresour. Technol. 101, 15581569. doi: 10.1016/j.biortech.2009.10.080

Dhar, K., Subashchandrabose, S. R., Venkateswarlu, K., Krishnan, K., and Megharaj, M. (2020). Anaerobic microbial degradation of polycyclic aromatic hydrocarbons: a comprehensive review. Rev. Environ. Contam. T. 251, 25-108. doi: 10.1007/398_2019_29

Duedahl-Olesen, L., Navaratnam, M. A., Jewula, J., and Jensen, A. (2015). PAH in some brands of tea and coffee. Polycycl. Aromat. Comp. 35, 74-90. doi: 10.1080/10406638.2014.918554

El Amrani, A., Dumas, A.-S., Wick, L. Y., Yergeau, E., and Berthomeì, R. (2015). Omics" insights into PAH degradation toward improved green remediation biotechnologies. Environ. Sci. Technol. 49, 11281-11291. doi: 10.1021/acs.est. 5 b01740

Eskandary, S., Tahmourespour, A., Hoodaji, M., and Abdollahi, A. (2017). The synergistic use of plant and isolated bacteria to clean up polycyclic aromatic hydrocarbons from contaminated soil. J. Environ. Health Sci. Eng. 15:12. doi: 10.1186/s40201-017-0274-2

Farias, J. M., Stamford, T. C. M., Resende, A. H. M., Aguiar, J. S., Rufino, R. D., Luna, J. M., et al. (2019). Mouthwash containing a biosurfactant and chitosan: an eco-sustainable option for the control of cariogenic microorganisms. Int. J. Biol. Macromol. 129, 853-860. doi: 10.1016/j.ijbiomac.2019.02.090

Flemming, H.-C., and Wingender, J. (2010). The biofilm matrix. Nat. Rev. Microbiol. 8, 623-633.

Forján, R., Lores, I., Sierra, C., Baragaño, D., Gallego, J. L. R., and Peláez, A. I. (2020). Bioaugmentation Treatment of a PAH-Polluted Soil in a Slurry Bioreactor. Appl. Sci. 10, 1-17.

Gan, S., Lau, E., and Ng, H. (2009). Remediation of soils contaminated with polycyclic aromatic hydrocarbons (PAHs). J. Hazard. Mater. 172, 532-549. doi: 10.1016/j.jhazmat.2009.07.118

García-Sánchez, M., Košnáø, Z., Mercl, F., Aranda, E., and Tlustoš, P. (2018). A comparative study to evaluate natural attenuation, mycoaugmentation, phytoremediation, and microbial-assisted phytoremediation strategies for the 
bioremediation of an aged PAH-polluted soil. Ecotoxicol. Environ. Saf. 147, 165-174. doi: 10.1016/j.ecoenv.2017.08.012

Ghosal, D., Ghosh, S., Dutta, T. K., and Ahn, Y. (2016). Current state of knowledge in microbial degradation of polycyclic aromatic hydrocarbons (PAHs): a review. Front. Microbiol. 7:1369. doi: 10.3389/fmicb.2016.01369

Gitipour, S., Sorial, G. A., Ghasemi, S., and Bazyari, M. (2018). Treatment technologies for PAH-contaminated sites: a critical review. Environ. Monit. Assess. 190, 1-17.

Gong, C., Huang, H., Qian, Y., Zhang, Z., and Wu, H. (2017). Integrated electrocoagulation and membrane filtration for PAH removal from realistic industrial wastewater: effectiveness and mechanisms. RSC Adv. 7, 52366-52374. doi: $10.1039 / \mathrm{c} 7 \mathrm{ra} 09372 \mathrm{a}$

Gou, Y., Zhao, Q., Yang, S., Qiao, P., Cheng, Y., Song, Y., et al. (2020). Enhanced degradation of polycyclic aromatic hydrocarbons in aged subsurface soil using integrated persulfate oxidation and anoxic biodegradation. Chem. Eng. J. 125040, 1-13.

Guo, Y., Rene, E. R., Wang, J., and Ma, W. (2020). Biodegradation of polyaromatic hydrocarbons and the influence of environmental factors during the cocomposting of sewage sludge and green forest waste. Bioresour. Technol. 297, 122434. doi: 10.1016/j.biortech.2019.122434

Gupta, S., and Pathak, B. (2020). "Mycoremediation of polycyclic aromatic hydrocarbons," in Abatement of Environmental Pollutants, eds A. Borthakur, P. Singh, and A. Kumar (Amsterdam: Elsevier), 127-149. doi: 10.1016/b978-0-12818095-2.00006-0

Gupte, A., Tripathi, A., Patel, H., Rudakiya, D., and Gupte, S. (2016). Bioremediation of polycyclic aromatic hydrocarbon (PAHs): a perspective. Open Biotechnol. J. 10, 363-378. doi: 10.2174/1874070701610010363

Haleyur, N., Shahsavari, E., Jain, S. S., Koshlaf, E., Ravindran, V. B., Morrison, P. D., et al. (2019). Influence of bioaugmentation and biostimulation on PAH degradation in aged contaminated soils: response and dynamics of the bacterial community. J. Environ. Manage. 238, 49-58. doi: 10.1016/j.jenvman.2019. 02.115

Haritash, A., and Kaushik, C. (2009). Biodegradation aspects of polycyclic aromatic hydrocarbons (PAHs): a review. J. Hazard. Mater. 169, 1-15. doi: 10.1016/j. jhazmat.2009.03.137

Harms, H., Schlosser, D., and Wick, L. Y. (2011). Untapped potential: exploiting fungi in bioremediation of hazardous chemicals. Nat. Rev. Microbiol. 9, 177192. doi: $10.1038 /$ nrmicro2519

He, Y., and Chi, J. (2019). Pilot-scale demonstration of phytoremediation of PAH-contaminated sediments by Hydrilla verticillata and Vallisneria spiralis. Environ. Technol. 40, 605-613. doi: 10.1080/09593330.2017.1398783

Helbling, D. E., Ackermann, M., Fenner, K., Kohler, H.-P. E., and Johnson, D. R. (2012). The activity level of a microbial community function can be predicted from its metatranscriptome. ISME J. 6, 902-904. doi: 10.1038/ismej.2011.158

Hong, Z., Chen, W., Rong, X., Cai, P., Dai, K., and Huang, Q. (2013). The effect of extracellular polymeric substances on the adhesion of bacteria to clay minerals and goethite. Chem. Geol. 360, 118-125. doi: 10.1016/j.chemgeo.2013.10.014

Hrudkova, M., Fiala, Z., Borska, L., Novosad, J., and Smolej, L. (2004). The effect of polycyclic aromatic hydrocarbons to bone marrow. Acta medica (Hradec Kralove). Supplementum 47, 75-81.

Huang, R.-Y., Tian, W.-J., Liu, Q., Yu, H.-B., Jin, X., Zhao, Y.-G., et al. (2016). Enhanced biodegradation of pyrene and indeno (1, 2, 3-cd) pyrene using bacteria immobilized in cinder beads in estuarine wetlands. Mar. Pollut. Bull. 102, 128-133. doi: 10.1016/j.marpolbul.2015.11.044

Ibrar, M., and Zhang, H. (2020). Construction of a hydrocarbon-degrading consortium and characterization of two new lipopeptides biosurfactants. Sci. Total Environ. 2019:136400. doi: 10.1016/j.scitotenv.2019.136400

Jia, C., Li, X., Allinson, G., Liu, C., and Gong, Z. (2016). Composition and morphology characterization of exopolymeric substances produced by the PAH-degrading fungus of Mucor mucedo. Environ. Sci. Pollut. Res. 23, 84218430. doi: $10.1007 / \mathrm{s} 11356-015-5986-1$

Jiang, Y., Zhang, Z., and Zhang, X. (2018). Co-biodegradation of pyrene and other PAHs by the bacterium Acinetobacter johnsonii. Ecotoxicol. Environ. Saf. 163, 465-470. doi: 10.1016/j.ecoenv.2018.07.065

Jimoh, A. A., and Lin, J. (2019). Biosurfactant: a new frontier for greener technology and environmental sustainability. Ecotoxicol. Environ. Saf. 184:109607. doi: 10.1016/j.ecoenv.2019.109607
Johnsen, A. R., and Karlson, U. (2007). Diffuse PAH contamination of surface soils: environmental occurrence, bioavailability, and microbial degradation. Appl. Microbiol. Biotechnol. 76, 533-543.

Kan, J., Peng, T., Huang, T., Xiong, G., and Hu, Z. (2020). NarL, a Novel Repressor for CYP108j1 Expression during PAHs Degradation in Rhodococcus sp. P14. Int. J. Mol. Sci. 21:983. doi: 10.3390/ijms21030983

Ke, L., Luo, L., Wang, P., Luan, T., and Tam, N. F.-Y. (2010). Effects of metals on biosorption and biodegradation of mixed polycyclic aromatic hydrocarbons by a freshwater green alga Selenastrum capricornutum. Bioresour. Technol. 101, 6950-6961. doi: 10.1016/j.biortech.2010.04.011

Khemili-Talbi, S., Kebbouche-Gana, S., Akmoussi-Toumi, S., Angar, Y., and Gana, M. L. (2015). Isolation of an extremely halophilic arhaeon Natrialba sp. C21 able to degrade aromatic compounds and to produce stable biosurfactant at high salinity. Extremophiles 19, 1109-1120. doi: 10.1007/s00792-015-0783-9

Kiely, P. D., Regan, J. M., and Logan, B. E. (2011). The electric picnic: synergistic requirements for exoelectrogenic microbial communities. Curr. Opin. Biotechnol. 22, 378-385. doi: 10.1016/j.copbio.2011.03.003

Kong, F.-X., Sun, G.-D., and Liu, Z.-P. (2018). Degradation of polycyclic aromatic hydrocarbons in soil mesocosms by microbial/plant bioaugmentation: performance and mechanism. Chemosphere 198, 83-91. doi: 10.1016/j. chemosphere.2018.01.097

Košnáø, Z., Mercl, F., and Tlustoš, P. (2020). Long-term willows phytoremediation treatment of soil contaminated by fly ash polycyclic aromatic hydrocarbons from straw combustion. Environ. Pollut. 114787, 1-9. doi: 10.1080/10406638. 2020.1825003

Kotoky, R., and Pandey, P. (2020). Rhizosphere mediated biodegradation of benzo (A) pyrene by surfactin producing soil bacilli applied through Melia azedarach rhizosphere. Int. J. Phytoremediat. 22, 363-372. doi: 10.1080/15226514.2019. 1663486

Kuppusamy, S., Thavamani, P., Venkateswarlu, K., Lee, Y. B., Naidu, R., and Megharaj, M. (2017). Remediation approaches for polycyclic aromatic hydrocarbons (PAHs) contaminated soils: technological constraints, emerging trends and future directions. Chemosphere 168, 944-968. doi: 10.1016/j. chemosphere.2016.10.115

Lamichhane, S., Krishna, K. B., and Sarukkalige, R. (2016). Polycyclic aromatic hydrocarbons (PAHs) removal by sorption: a review. Chemosphere 148, 336353. doi: 10.1016/j.chemosphere.2016.01.036

Lee, B.-K., and Vu, V. T. (2010). "Sources, distribution and toxicity of polyaromatic hydrocarbons (PAHs) in particulate matter," in Air Pollution, (London: IntechOpen), 99-122.

Lemaire, J., Laurent, F., Leyval, C., Schwartz, C., Buès, M., and Simonnot, M.O. (2013). PAH oxidation in aged and spiked soils investigated by column experiments. Chemosphere 91, 406-414. doi: 10.1016/j.chemosphere.2012. 12.003

Li, F., Guo, S., Wu, B., and Wang, S. (2020). Pilot-scale electro-bioremediation of heavily PAH-contaminated soil from an abandoned coking plant site. Chemosphere 244:125467. doi: 10.1016/j.chemosphere.2019.125467

Li, S., Luo, J., Hang, X., Zhao, S., and Wan, Y. (2019). Removal of polycyclic aromatic hydrocarbons by nanofiltration membranes: rejection and fouling mechanisms. J. Membrane Sci. 582, 264-273. doi: 10.1016/j.memsci.2019. 04.008

Li, Y., Xu, L., Gong, H., Ding, B., Dong, M., and Li, Y. (2017). A microbial exopolysaccharide produced by Sphingomonas species for enhanced heavy oil recovery at high temperature and high salinity. Energ. Fuel 31, 3960-3969. doi: 10.1021/acs.energyfuels.6b02923

Liang, C., Huang, Y., Wang, Y., Ye, Q., Zhang, Z., and Wang, H. (2019). Distribution of bacterial polycyclic aromatic hydrocarbon (PAH) ringhydroxylating dioxygenases genes in oilfield soils and mangrove sediments explored by gene-targeted metagenomics. Appl. Microbiol. Biotechnol. 103, 2427-2440. doi: 10.1007/s00253-018-09613-x

Liu, X., Ge, W., Zhang, X., Chai, C., Wu, J., Xiang, D., et al. (2019). Biodegradation of aged polycyclic aromatic hydrocarbons in agricultural soil by Paracoccus sp. LXC combined with humic acid and spent mushroom substrate. J. Hazard. Mater. 379, 1-10.

Logan, B. E., Hamelers, B., Rozendal, R., Schröder, U., Keller, J., Freguia, S., et al. (2006). Microbial fuel cells: methodology and technology. Environ. Sci. Technol. 40, 5181-5192. 
Lors, C., Damidot, D., Ponge, J.-F., and Périé, F. (2012). Comparison of a bioremediation process of PAHs in a PAH-contaminated soil at field and laboratory scales. Environ. Pollut. 165, 11-17. doi: 10.1016/j.envpol.2012. 02.004

Lu, X.-Y., Zhang, T., and Fang, H. H.-P. (2011). Bacteria-mediated PAH degradation in soil and sediment. Appl. Microbiol. Biotechnol. 89, 1357-1371. doi: 10.1007/s00253-010-3072-7

Ma, J., and Zhai, G. (2012). Microbial bioremediation in omics era: opportunities and challenges. J. Bioremed. Biodeg 3:e120. doi: 10.4172/2155-6199.1000 e120

Malla, M. A., Dubey, A., Yadav, S., Kumar, A., Hashem, A., and Abd_Allah, E. F. (2018). Understanding and designing the strategies for the microbe-mediated remediation of environmental contaminants using omics approaches. Front. Microbiol. 9:1132. doi: 10.3389/fmicb.2018.01132

Mallick, S., Chakraborty, J., and Dutta, T. K. (2011). Role of oxygenases in guiding diverse metabolic pathways in the bacterial degradation of low-molecularweight polycyclic aromatic hydrocarbons: a review. Crit. Rev. Microbiol. 37, 64-90. doi: 10.3109/1040841x.2010.512268

Manousi, N., and Zachariadis, G. A. (2020). Recent advances in the extraction of polycyclic aromatic hydrocarbons from environmental samples. Molecules 25:2182. doi: 10.3390/molecules25092182

Mao, Y., Mingming, S., Shanni, X., Kuan, L., Yanfang, F., Yu, Z., et al. (2017). Feasibility of tea saponin-enhanced soil washing in a soybean oil-water solvent system to extract PAHs/Cd/Ni efficiently from a coking plant site. Pedosphere 27, 452-464. doi: 10.1016/s1002-0160(17)60341-2

Marris, C., Kompella, S. N., Miller, M., Incardona, J. P., Brette, F., Hancox, J. C., et al. (2020). Polyaromatic hydrocarbons in pollution: a heart-breaking matter. J. Physiol. 598, 227-247. doi: 10.1113/jp278885

Mehetre, G. T., Dastager, S. G., and Dharne, M. S. (2019). Biodegradation of mixed polycyclic aromatic hydrocarbons by pure and mixed cultures of biosurfactant producing thermophilic and thermo-tolerant bacteria. Sci. Total Environ. 679, 52-60. doi: 10.1016/j.scitotenv.2019.04.376

Miura, K., Shimada, K., Sugiyama, T., Sato, K., Takami, A., Chan, C. K., et al. (2019). Seasonal and annual changes in PAH concentrations in a remote site in the Pacific Ocean. Sci. Rep. 9, 1-10.

Mohan, S. V., Kisa, T., Ohkuma, T., Kanaly, R. A., and Shimizu, Y. (2006). Bioremediation technologies for treatment of PAH-contaminated soil and strategies to enhance process efficiency. Rev. Environ. Sci. Biotechnol. 5, 347374. doi: 10.1007/s11157-006-0004-1

Mojiri, A., Zhou, J. L., Ohashi, A., Ozaki, N., and Kindaichi, T. (2019). Comprehensive review of polycyclic aromatic hydrocarbons in water sources, their effects and treatments. Sci. Total Environ. 2019:133971. doi: 10.1016/j. scitotenv.2019.133971

More, T., Yadav, J. S. S., Yan, S., Tyagi, R. D., and Surampalli, R. Y. (2014). Extracellular polymeric substances of bacteria and their potential environmental applications. J. Environ. Manage. 144, 1-25. doi: 10.1016/j. jenvman.2014.05.010

Moscovici, M. (2015). Present and future medical applications of microbial exopolysaccharides. Front. Microbiol. 6:1012. doi: 10.3389/fmicb.2015. 01012

Mrozik, A., and Piotrowska-Seget, Z. (2010). Bioaugmentation as a strategy for cleaning up of soils contaminated with aromatic compounds. Microbiol. Res. 165, 363-375. doi: 10.1016/j.micres.2009.08.001

Muangchinda, C., Rungsihiranrut, A., Prombutara, P., Soonglerdsongpha, S., and Pinyakong, O. (2018). 16S metagenomic analysis reveals adaptability of a mixed-PAH-degrading consortium isolated from crude oil-contaminated seawater to changing environmental conditions. J. Hazard. Mater. 357, 119127. doi: 10.1016/j.jhazmat.2018.05.062

Nie, M., Yin, X., Ren, C., Wang, Y., Xu, F., and Shen, Q. (2010). Novel rhamnolipid biosurfactants produced by a polycyclic aromatic hydrocarbondegrading bacterium Pseudomonas aeruginosa strain NY3. Biotechnol. Adv. 28, 635-643. doi: 10.1016/j.biotechadv.2010.05.013

Ojha, N., Mandal, S. K., and Das, N. (2019). Enhanced degradation of indeno (1, 2, 3-cd) pyrene using Candida tropicalis NN4 in presence of iron nanoparticles and produced biosurfactant: a statistical approach. 3 Biotech 9 ,

Okere, U., and Semple, K. (2012). Biodegradation of PAHs in 'pristine'soils from different climatic regions. J. Bioremed. Biodegrad. S1:006. doi: 10.4172/21556199.S1-006
Paschke, M., Hutzler, C., Brinkmann, J., Henkler, F., and Luch, A. (2015). Polycyclic aromatic hydrocarbons in newspaper inks: migration, metabolism, and genotoxicity in human skin. Polycycl. Aromat. Comp. 35, 32-40. doi: 10.1080/10406638.2014.900643

Patel, A. B., Mahala, K., Jain, K., and Madamwar, D. (2018). Development of mixed bacterial cultures DAK11 capable for degrading mixture of polycyclic aromatic hydrocarbons (PAHs). Bioresour. Technol. 253, 288-296. doi: 10.1016/ j.biortech.2018.01.049

Patel, A. B., Singh, S., Patel, A., Jain, K., Amin, S., and Madamwar, D. (2019). Synergistic biodegradation of phenanthrene and fluoranthene by mixed bacterial cultures. Bioresour. Technol. 284, 115-120. doi: 10.1016/j.biortech. 2019.03.097

Peluffo, M., Rosso, J. A., Morelli, I. S., and Mora, V. C. (2018). Strategies for oxidation of PAHs in aged contaminated soil by batch reactors. Ecotoxicol. Environ. Saf. 151, 76-82. doi: 10.1016/j.ecoenv.2017.12.067

Peng, T., Luo, A., Kan, J., Liang, L., Huang, T., and Hu, Z. (2018). Identification of a ring-hydroxylating dioxygenases capable of anthracene and benz [a] anthracene oxidization from Rhodococcus sp. P14. J. Mol. Microbiol. Biotechnol. 28, 183-189. doi: 10.1159/000494384

Peng, X., Xu, P.-F., Du, H., Tang, Y., Meng, Y., Yuan, L., et al., (2018). Degradation of polycyclic aromatic hydrocarbons: a review. Appl. Ecol. Environ. Res. 16, 6419-6440.

Perera, F. P., Chang, H.-W., Tang, D., Roen, E. L., Herbstman, J., Margolis, A., et al. (2014). Early-life exposure to polycyclic aromatic hydrocarbons and ADHD behavior problems. PLoS One 9:e111670. doi: 10.1371/journal.pone.0111670

Purwasena, I. A., Astuti, D. I., Syukron, M., Amaniyah, M., and Sugai, Y. (2019). Stability test of biosurfactant produced by Bacillus licheniformis DS1 using experimental design and its application for MEOR. J. of Pet. Sci. and Eng. 183:106383. doi: 10.1016/j.petrol.2019.106383

Quintero, W. V., and Zafra, G. (2016). Use of molecular tools to monitor microbial communities during the bioremediation of polycyclic aromatic hydrocarboncontaminated soils. J. Ind. Pollut. Control 32, 534-543.

Rahman, S., Masdar, M., Rosli, M. I., Majlan, E., Husaini, T., Kamarudin, S., et al. (2016). Overview biohydrogen technologies and application in fuel cell technology. Renew. Sust. Energ. Rev. 66, 137-162. doi: 10.1016/j.rser.2016. 07.047

Rajpara, R. K., Dudhagara, D. R., Bhatt, J. K., Gosai, H. B., and Dave, B. P. (2017). Polycyclic aromatic hydrocarbons (PAHs) at the Gulf of Kutch, Gujarat, India: occurrence, source apportionment, and toxicity of PAHs as an emerging issue. Mar. Pollut. Bull. 119, 231-238. doi: 10.1016/j.marpolbul.2017.04.039

Ravindra, K., Sokhi, R., and Van Grieken, R. (2008). Atmospheric polycyclic aromatic hydrocarbons: source attribution, emission factors and regulation. Atmos. Environ. 42, 2895-2921. doi: 10.1016/j.atmosenv.2007.12.010

Ravindran, A., Sajayan, A., Priyadharshini, G. B., Selvin, J., and Kiran, G. S. (2020). Revealing the efficacy of thermostable biosurfactant in heavy metal bioremediation and surface treatment in vegetables. Front. Microbiol. 11:222. doi: $10.3389 /$ fmicb.2020.00222

Redfern, L. K., Gardner, C. M., Hodzic, E., Ferguson, P. L., Hsu-Kim, H., and Gunsch, C. K. (2019). A new framework for approaching precision bioremediation of PAH contaminated soils. J. Hazard. Mater. 378:120859. doi: 10.1016/j.jhazmat.2019.120859

Rengarajan, T., Rajendran, P., Nandakumar, N., Lokeshkumar, B., Rajendran, P., and Nishigaki, I. (2015). Exposure to polycyclic aromatic hydrocarbons with special focus on cancer. Asian Pac. J. Trop. Biomed. 5, $182-189$.

Rorat, A., Wloka, D., Grobelak, A., Grosser, A., Sosnecka, A., Milczarek, M., et al. (2017). Vermiremediation of polycyclic aromatic hydrocarbons and heavy metals in sewage sludge composting process. J. Environ. Manage. 187, 347-353. doi: 10.1016/j.jenvman.2016.10.062

Rose, M., Holland, J., Dowding, A., Petch, S. R., White, S., Fernandes, A., et al. (2015). Investigation into the formation of PAHs in foods prepared in the home to determine the effects of frying, grilling, barbecuing, toasting and roasting. Food Chem. Toxicol. 78, 1-9. doi: 10.1016/j.fct.2014.12.018

Sangkharak, K., Choonut, A., Rakkan, T., and Prasertsan, P. (2020). The degradation of phenanthrene, pyrene, and fluoranthene and its conversion into medium-chain-length polyhydroxyalkanoate by novel polycyclic aromatic hydrocarbon-degrading bacteria. Curr. Microbiol. 77, 897-909. doi: 10.1007/ s00284-020-01883-x 
Sayara, T., Pognani, M., Sarrà, M., and Sánchez, A. (2010). Anaerobic degradation of PAHs in soil: impacts of concentration and amendment stability on the PAHs degradation and biogas production. Int. Biodeter. Biodegr. 64, 286-292. doi: 10.1016/j.ibiod.2010.02.005

Shah, M. P. (2014). Environmental bioremediation: a low cost nature's natural biotechnology for environmental clean-up. J. Pet. Environ. Biotechnol. 5:4. doi: 10.4172/2157-7463.1000191

Shanker, U., Jassal, V., and Rani, M. (2017). Green synthesis of iron hexacyanoferrate nanoparticles: potential candidate for the degradation of toxic PAHs. J. Environ. Chem. Eng. 5, 4108-4120. doi: 10.1016/j.jece.2017.07.042

Sharma, A., Singh, S. B., Sharma, R., Chaudhary, P., Pandey, A. K., Ansari, R., et al. (2016). Enhanced biodegradation of PAHs by microbial consortium with different amendment and their fate in in-situ condition. J. Environ. Manage. 181, 728-736. doi: 10.1016/j.jenvman.2016.08.024

Sherafatmand, M., and Ng, H. Y. (2015). Using sediment microbial fuel cells (SMFCs) for bioremediation of polycyclic aromatic hydrocarbons (PAHs). Bioresour. Technol. 195, 122-130. doi: 10.1016/j.biortech.2015.06.002

Shojaipour, M., Ghaemy, M., and Amininasab, S. M. (2020). Removal of NO3ions from water using bioadsorbent based on gum tragacanth carbohydrate biopolymer. Carbohydr. Polym. 227:115367. doi: 10.1016/j.carbpol.2019. 115367

Silva-Castro, G. A., Uad, I., Rodríguez-Calvo, A., González-López, J., and Calvo, C. (2015). Response of autochthonous microbiota of diesel polluted soils to land-farming treatments. Environ. Res. 137, 49-58. doi: 10.1016/j.envres.2014. 11.009

Sinha, R. K., Bharambe, G., and Ryan, D. (2008). Converting wasteland into wonderland by earthworms-a low-cost nature's technology for soil remediation: a case study of vermiremediation of PAHs contaminated soil. Environmentalist 28, 466-475. doi: 10.1007/s10669-008-9171-7

Skupinska, K., Misiewicz, I., and Kasprzycka-Guttman, T. (2004). Polycyclic aromatic hydrocarbons: physicochemical properties, environmental appearance and impact on living organisms. Acta Pol. Pharm. 61, 233-240.

Smith, T. L., Merry, S. T., Harris, D. L., Ford, J. J., Ike, J., Archibong, A. E., et al. (2007). Species-specific testicular and hepatic microsomal metabolism of benzo (a) pyrene, an ubiquitous toxicant and endocrine disruptor. Toxicol. in vitro 21, 753-758. doi: 10.1016/j.tiv.2007.01.005

Smol, M., and Włodarczyk-Makuła, M. (2012). Effectiveness in the removal of Polycyclic Aromatic Hydrocarbons from industrial wastewater by ultrafiltration technique. Arch. Environ. Prot. 38, 49-58. doi: 10.2478/v10265-012-0040-6

Smol, M., Włodarczyk-Makuła, M., Mielczarek, K., Bohdziewicz, J., and Włóka, D. (2016). The use of reverse osmosis in the removal of PAHs from municipal landfill leachate. Polycycl. Aromat. Compd. 36, 20-39. doi: 10.1080/10406638. 2014.957403

Song, Y., Fang, G., Zhu, C., Zhu, F., Wu, S., Chen, N., et al. (2019). Zero-valent iron activated persulfate remediation of polycyclic aromatic hydrocarboncontaminated soils: an in situ pilot-scale study. Chem. Eng. J. 355, 65-75. doi: 10.1016/j.cej.2018.08.126

Srogi, K. (2007). Monitoring of environmental exposure to polycyclic aromatic hydrocarbons: a review. Environ. Chem. Lett. 5, 169-195. doi: 10.1007/s10311007-0095-0

Storey, S., Ashaari, M. M., Clipson, N., Doyle, E., and de Menezes, A. B. (2018). Opportunistic bacteria dominate the soil microbiome response to phenanthrene in a microcosm-based study. Front. Microbiol. 9:2815. doi: 10. 3389/fmicb.2018.02815

Subashchandrabose, S. R., Venkateswarlu, K., Venkidusamy, K., Palanisami, T., Naidu, R., and Megharaj, M. (2019). Bioremediation of soil long-term contaminated with PAHs by algal- bacterial synergy of Chlorella sp. MM3 and Rhodococcus wratislaviensis strain 9 in slurry phase. Sci. Total Environ. 659, 724-731. doi: 10.1016/j.scitotenv.2018.12.453

Suman, S., Sinha, A., and Tarafdar, A. (2016). Polycyclic aromatic hydrocarbons (PAHs) concentration levels, pattern, source identification and soil toxicity assessment in urban traffic soil of Dhanbad. India. Sci. Total Environ. 545, 353-360. doi: 10.1016/j.scitotenv.2015.12.061

Sun, Q., Li, H., Yan, J., Liu, L., Yu, Z., and Yu, X. (2015). Selection of appropriate biogas upgrading technology-a review of biogas cleaning, upgrading and utilisation. Renew. Sust. Energ. Rev. 51, 521-532. doi: 10.1016/j.rser.2015.06.029

Tao, W., Lin, J., Wang, W., Huang, H., and Li, S. (2020). Biodegradation of aliphatic and polycyclic aromatic hydrocarbons by the thermophilic bioemulsifier-producing Aeribacillus pallidus strain SL-1. Ecotoxicol. Environ. Saf. 189:109994. doi: 10.1016/j.ecoenv.2019.109994

Tong, R., Yang, X., Su, H., Pan, Y., Zhang, Q., Wang, J., et al. (2018). Levels, sources and probabilistic health risks of polycyclic aromatic hydrocarbons in the agricultural soils from sites neighboring suburban industries in Shanghai. Sci. Total Environ. 616, 1365-1373. doi: 10.1016/j.scitotenv.2017.10.179

Tripathi, V., Gaur, V. K., Dhiman, N., Gautam, K., and Manickam, N. (2019). Characterization and properties of the biosurfactant produced by PAHdegrading bacteria isolated from contaminated oily sludge environment. Environ. Sci. Pollut. Res. 27, 27268-27278. doi: 10.1007/s11356-019-05591-3

Ukiwe, L. N., Egereonu, U. U., Njoku, P. C., Nwoko, C. I., and Allinor, J. I. (2013). Polycyclic aromatic hydrocarbons degradation techniques. Int. J. Chem. $5,43-55$.

Usman, M., Hanna, K., and Haderlein, S. (2016). Fenton oxidation to remediate PAHs in contaminated soils: a critical review of major limitations and counterstrategies. Sci. Total Environ. 569, 179-190. doi: 10.1016/j.scitotenv.2016. 06.135

Vaidya, S., Devpura, N., Jain, K., and Madamwar, D. (2018). Degradation of chrysene by enriched bacterial consortium. Front. Microbiol. 9:1333. doi: 10. 3389/fmicb.2018.01333

Vaidya, S., Jain, K., and Madamwar, D. (2017). Metabolism of pyrene through phthalic acid pathway by enriched bacterial consortium composed of Pseudomonas, Burkholderia, and Rhodococcus (PBR). 3 Biotech 7:29. doi: 10. 1007/s13205-017-0598-8

Wang, C., Fan, Q., Zhang, X., Lu, X., Xu, Y., Zhu, W., et al. (2018). Isolation, characterization, and pharmaceutical applications of an exopolysaccharide from Aerococcus Uriaeequi. Mar. Drugs 16:337. doi: 10.3390/md16090337

Wang, C., Li, Y., Tan, H., Zhang, A., Xie, Y., Wu, B., et al. (2019). A novel microbe consortium, nano-visible light photocatalyst and microcapsule system to degrade PAHs. Chem. Eng. J. 359, 1065-1074. doi: 10.1016/j.cej.2018. 11.077

Wang, C., Liu, H., Li, J., and Sun, H. (2014). Degradation of PAHs in soil by Lasiodiplodia theobromae and enhanced benzo [a] pyrene degradation by the addition of Tween-80. Environ. Sci. Pollut. Res. 21, 10614-10625. doi: 10.1007/ s11356-014-3050- 1

Wang, H., Kim, B., and Wunder, S. L. (2015). Nanoparticle-supported lipid bilayers as an in situ remediation strategy for hydrophobic organic contaminants in soils. Environ. Sci. Technol. 49, 529-536. doi: 10.1021/es504832n

Wang, H., Wang, X., Liu, C., Wang, Y., Rong, L., Sun, L., et al. (2017). In-Situ bioremediation of DDTs and PAH contaminated aging farmland soil using blood meal. Soil Sediment Contam. 26, 623-635. doi: 10.1080/15320383.2017. 1385593

Wen, S., Zhao, J., Sheng, G., and Fu, J. (2003). Photocatalytic reactions of pyrene at TiO2/water interfaces. Chemosphere 50, 111-119. doi: 10.1016/s0045-6535(02) 00420-4

Wu, H., Sun, B., and Li, J. (2019). Polycyclic Aromatic Hydrocarbons in Sediments/Soils of the Rapidly Urbanized Lower Reaches of the River Chaohu, China. Int. J. Environ. Res. Public Health 16:2302. doi: 10.3390/ijerph1613 2302

$\mathrm{Wu}, \mathrm{Y}$., Xu, Y., and Zhou, N. (2020). A newly defined dioxygenase system from Mycobacterium vanbaalenii PYR-1 endowed with an enhanced activity of dihydroxylation of high-molecular-weight polyaromatic hydrocarbons. Front. Env. Sci. Eng. 14:14. doi: 10.1007/s11783-019-1193-5

Xinhong, G., Ying, T., Wenjie, R., Jun, M., Christie, P., and Yongming, L. (2017). Optimization of ex-situ washing removal of polycyclic aromatic hydrocarbons from a contaminated soil using nano-sulfonated graphene. Pedosphere 27, 527-536. doi: 10.1016/s1002-0160(17)60348-5

Xu, S., Wang, W., and Zhu, L. (2019). Enhanced microbial degradation of benzo [a] pyrene by chemical oxidation. Sci. Total Environ. 653, 1293-1300. doi: 10.1016/j.scitotenv.2018.10.444

Yadu, A., Sahariah, B., and Anandkumar, J. (2019). Novel bioremediation approach for treatment of naphthalene, ammonia-N and Sulphate in Fed-batch Reactor. J. Environ. Chem. Eng. 7:103388. doi: 10.1016/j.jece.2019.103388

Yan, J., Wang, L., Fu, P. P., and Yu, H. (2004). Photomutagenicity of 16 polycyclic aromatic hydrocarbons from the US EPA priority pollutant list. Mutat. Res. Gen. Tox. En. 557, 99-108. doi: 10.1016/j.mrgentox.2003.10.004

Yang, X., Li, E., Liu, F., and Xu, M. (2020). Interactions of PAH-degradation and nitrate-/sulfate-reducing assemblages in anaerobic sediment microbial 
community. J. Hazard. Mater. 2020:122068. doi: 10.1016/j.jhazmat.2020. 122068

Yu, B., Tian, J., and Feng, L. (2017). Remediation of PAH polluted soils using a soil microbial fuel cell: influence of electrode interval and role of microbial community. J. Hazard. Mater. 336, 110-118. doi: 10.1016/j.jhazmat.2017.04.066

Yu, H. (2002). Environmental carcinogenic polycyclic aromatic hydrocarbons: photochemistry and phototoxicity. J. Environ. Sci. Heal. C 20, 149-183. doi: 10.1081/gnc- 120016203

Zelinkova, Z., and Wenzl, T. (2015). The occurrence of 16 EPA PAHs in fooda review. Polycycl. Aromat. Comp. 35, 248-284. doi: 10.1080/10406638.2014. 918550

Zeneli, A., Kastanaki, E., Simantiraki, F., and Gidarakos, E. (2019). Monitoring the biodegradation of TPH and PAHs in refinery solid waste by biostimulation and bioaugmentation. J. Environ. Chem. Eng. 7, 1-7.

Zhang, H., Zhang, X., and Geng, A. (2020). Expression of a novel manganese peroxidase from Cerrena unicolor BBP6 in Pichia pastoris and its application in dye decolorization and PAH degradation. Biochem. Eng. J. 153, 107402. doi: 10.1016/j.bej.2019.107402

Zhang, S., Hu, Z., and Wang, H. (2019). Metagenomic analysis exhibited the co-metabolism of polycyclic aromatic hydrocarbons by bacterial community from estuarine sediment. Environ. Int. 129, 308-319. doi: 10.1016/j.envint.2019. 05.028

Zhao, D., Liao, X., Yan, X., Huling, S. G., Chai, T., and Tao, H. (2013). Effect and mechanism of persulfate activated by different methods for PAHs removal in soil. J. Hazard. Mater. 254, 228-235. doi: 10.1016/j.jhazmat.2013. 03.056

Zheng, H., Xing, X., Hu, T., Zhang, Y., Zhang, J., Zhu, G., et al. (2018). Biomass burning contributed most to the human cancer risk exposed to the soil-bound PAHs from Chengdu Economic Region, western China. Ecotoxicol. Environ. Saf. 159, 63-70. doi: 10.1016/j.ecoenv.2018. 04.065

Conflict of Interest: The authors declare that this review article compilation was conducted in the absence of any conflict of interest.

Copyright $\odot 2020$ Patel, Shaikh, Jain, Desai and Madamwar. This is an open-access article distributed under the terms of the Creative Commons Attribution License (CC BY). The use, distribution or reproduction in other forums is permitted, provided the original author(s) and the copyright owner(s) are credited and that the original publication in this journal is cited, in accordance with accepted academic practice. No use, distribution or reproduction is permitted which does not comply with these terms. 